\title{
CrystEngComm
}

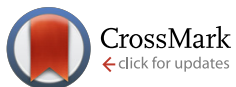

Cite this: CrystEngComm, 2015, 17, 6753

Received 3rd July 2015,

Accepted 3rd August 2015

DOI: $10.1039 / c 5 c e 01294 e$

www.rsc.org/crystengcomm

\section{Cobalt(II/III), nickel(II) and copper(II) coordination clusters employing a monoanionic Schiff base ligand: synthetic, topological and computational mechanistic aspects $\dagger$}

\author{
Edward Loukopoulos, ${ }^{a}$ Benjamin Berkoff, ${ }^{a}$ Kieran Griffiths, ${ }^{a}$ Victoria Keeble, ${ }^{a}$ \\ Vassiliki N. Dokorou, ${ }^{a}$ Athanassios C. Tsipis, ${ }^{* b}$ Albert Escuer $^{c}$ \\ and George E. Kostakis*a
}

Nine mono-, di- and tetranuclear coordination clusters ( $\left.M=\mathrm{CO}^{\prime \prime \prime I I I}, \mathrm{Ni}^{\prime \prime}, \mathrm{Cu}^{\prime \prime}\right)$ using a monoanionic Schiff base ligand were synthesized and characterized by X-ray crystallography. A series of transformations occur in the ligand in certain compounds for which theoretical studies are presented. Synthetic aspects, topological issues and magnetic studies are discussed.

\section{Introduction}

Despite the long history and activity of polynuclear metal complexes, also known as coordination clusters $(\mathrm{CCs}),{ }^{1}$ their coordination chemistry continues to be a field that attracts great interest today. Among the different categories of ligands used in this field, perhaps one of the most significant is Schiff bases, which have received a large amount of attention especially in the past decade. This is due to their wide range of useful properties such as strong biological activity, ${ }^{2-4}$ ease of access and versatile coordination abilities. As a result, CCs using ligands of this nature are of special importance and many examples of their applications in materials science, ${ }^{5-7}$ catalysis, ${ }^{8-12}$ biological processes, ${ }^{13-15}$ molecular magnetic materials, ${ }^{16-23}$ photochemistry, ${ }^{24,25}$ and nanostructure studies $^{26,27}$ have been explored.

In particular, Schiff bases formed from $o$-vanillin as starting material have been of significant interest and their

\footnotetext{
${ }^{a}$ Department of Chemistry, School of Life Sciences, University of Sussex, Brighton BN1 9QJ, UK. E-mail: G.Kostakis@sussex.ac.uk

${ }^{b}$ Laboratory of Inorganic and General Chemistry, Department of Chemistry, University of Ioannina, 45110 Ioannina, Greece. E-mail: attsipis@uoi.gr

${ }^{c}$ Departamento de Quimica Inorganica, Universitat de Barcelona, Diagonal 645, 08028 Barcelona, Spain

$\dagger$ Electronic supplementary information (ESI) available: X-ray crystallographic files in CIF format for structures 1-10. Crystallographic parameters can be found in Tables S1 and S2. Scheme S1. Selected bond distances and angles for 1-9 can be found in Tables S3-S10. Cartesian coordinates and energies of the $\mathrm{L}^{n}(n=1-$ 4) ligands, the reactant, intermediate, transition state and product cobalt complexes located on the potential energy surfaces of the transformations the coordinated ligands undergo (Table S12). A library of the 100 polynuclear CCs with nuclearity over 3 is provided as an Excel file. CCDC 1400124-1400133. For ESI and crystallographic data in CIF or other electronic format see DOI: 10.1039/ c5ce01294e
}

coordination abilities along with various metal centres have been investigated thoroughly, leading to very interesting results. ${ }^{28-41}$ For example, the usage of a Schiff base formed between $\mathrm{L}$-glutamic acid and $o$-vanillin along with $\mathrm{Ni}\left(\mathrm{NO}_{3}\right)_{2}$ $\cdot 6 \mathrm{H}_{2} \mathrm{O}$ results in an intriguing 15-nickel metallomacrocyclic complex. ${ }^{31}$ Ferromagnetic and ferroelectric properties were observed in two enantiomerically pure nanoscale manganese CCs supported by chiral Schiff base ligands, ${ }^{29}$ while the pentanuclear compound $\mathrm{Mn}_{3}{ }^{\mathrm{III}} \mathrm{Ca}^{\mathrm{II}} \mathrm{Na}^{\mathrm{I}}$ appeared to be a sufficient catalyst for water oxidation. ${ }^{42}$<smiles>COc1cccc(/C=N/c2c(C)n(C)n(-c3cccc(Oc4cccc(/C=N/c5c(CO)n(C)n(-c6ccccc6)c5=O)c4O)c3)c2=O)c1O</smiles><smiles>CCOC(=O)c1c(N=Cc2cccc(OC)c2O)c(=O)n(-c2ccccc2)n1C</smiles>

Scheme 1 The protonated form of (E)-4-(2-hydroxy-3methoxybenzylideneamino)-2,3-dimethyl-1-phenyl-1,2-dihydropyrazol-5-one $\left(\mathrm{HL}^{1}\right)$ ligand used in this study. The different transformations of the $\mathrm{HL}^{1}$ ligand observed in compounds 5-7 $\mathrm{H}_{2} \mathrm{~L}^{2}$, $\mathrm{H}_{3} \mathrm{~L}^{3}, \mathrm{H}_{2} \mathrm{~L}^{4}$ ). Transformed organic molecules are presented in their protonated form. 
However, according to a CSD $\operatorname{search}^{43}$ all previously reported $o$-vanillin-based Schiff base ligands used for the synthesis of polynuclear CCs were derived mainly through a condensation of $o$-vanillin along with either amino alcohol such as 2-aminoethanol ${ }^{44}$ or amino acid $^{31,45}$ to produce di- or triprotic organic species. Based on this observation, we recently decided to study the coordination abilities of a Schiff base ligand derived from the condensation of $o$-vanillin and 4-aminoantipyrine and named (E)-4-(2-hydroxy-3methoxybenzylideneamino)-2,3-dimethyl-1-phenyl-1,2dihydropyrazol-5-one ( $\mathrm{HL}^{1}$, Scheme 1). ${ }^{46}$ Despite providing similar coordination modes to other diprotic ligands, i.e. those derived from $o$-vanillin and 2-aminoethanol or 2-aminophenol, $\mathrm{HL}^{1}$ is monoanionic and thus is anticipated to lead to unprecedented topologies. Indeed, the employment of $\mathrm{HL}^{1}$ in $\mathrm{Co}^{\mathrm{II}} / \mathrm{Dy}{ }^{\mathrm{III}}$ chemistry resulted in a series of polynuclear $\mathrm{Co}^{\mathrm{II}}{ }_{x} \mathrm{Dy}{ }_{y}^{\mathrm{III}}$ CCs displaying previously unseen topologies and interesting magnetic properties. ${ }^{46,47}$ The formation of the aforementioned high nuclearity $\mathrm{CC}$, using solely $\mathrm{HL}^{1}$, is in contrast to what has been achieved with other diprotic ligands that provide similar coordination environment, which resulted in tri- or tetranuclear CCs. ${ }^{37,48-50}$

In this study, we report the initial employment of $\mathrm{HL}^{1}$ in $\mathrm{Co}^{\mathrm{II}, \mathrm{III}}, \mathrm{Ni}^{\mathrm{II}}$ and $\mathrm{Cu}^{\mathrm{II}}$ chemistry and thus present the synthesis, characterization and crystal structure of nine CCs formulated as $\left[\mathrm{Co}^{\mathrm{II}} \mathrm{L}_{2}{ }_{2}\right] \cdot 5 \mathrm{MeCN} \quad(1.5 \mathrm{MeCN}), \quad\left[\mathrm{Ni}^{\mathrm{II}} \mathrm{L}_{2}{ }_{2}\right] \cdot 5 \mathrm{MeCN}$ $(2 \cdot 5 \mathrm{MeCN}),\left[\mathrm{Cu}^{\mathrm{II}} \mathrm{L}_{2}{ }_{2}\right] \cdot \mathrm{MeCN}(3 \cdot \mathrm{MeCN}),\left[\mathrm{Co}^{\mathrm{II}}{ }_{4} \mathrm{~L}_{4}{ }_{4}(\mathrm{MeO})_{2}\right] \cdot 2\left(\mathrm{ClO}_{4}\right)$ (4), $\left[\mathrm{Co}^{\mathrm{II}}{ }_{4} \mathrm{~L}^{2}{ }_{4}\left(\mathrm{H}_{2} \mathrm{O}\right)_{4}\right](5),\left[\mathrm{Co}_{4}{ }_{4} \mathrm{~L}^{3}{ }_{4}\left(\mathrm{H}_{2} \mathrm{O}\right)_{4}\right](6),\left[\mathrm{Co}^{\mathrm{III}} \mathrm{L}^{1} \mathrm{~L}^{4}\right] \cdot 2 \mathrm{MeCN}$ $(7 \cdot 2 \mathrm{MeCN}),\left[\mathrm{Ni}_{2}{ }_{2} \mathrm{~L}_{3}{ }_{3}(\mathrm{MeOH})\right] \cdot\left(\mathrm{ClO}_{4}\right) \cdot 2 \mathrm{MeOH}(8 \cdot 2 \mathrm{MeOH})$, and $\left[\mathrm{Cu}^{\mathrm{II}}{ }_{4} \mathrm{~L}^{1}{ }_{4}(\mathrm{MeO})_{2}\right] \cdot 2\left(\mathrm{ClO}_{4}\right) \cdot 6 \mathrm{MeOH}(9 \cdot 6 \mathrm{MeOH})$ as well as the magnetic properties for representative compounds 4 and 8 . Synthetic and topological issues are discussed. In addition, we report interesting cases of ligand transformation found in 4-7 supported by theoretical density functional theory studies, which give valuable insight into the direct mechanism taking place during these transformations.

\section{Experimental}

\section{Materials and methods}

Materials. Chemicals (reagent grade) were purchased from Sigma-Aldrich and Alfa Aesar. All experiments were performed under aerobic conditions using materials and solvents as received. Safety note: Perchlorate salts are potentially explosive; such compounds should be used in small quantities and handled with caution and utmost care at all times.

Instrumentation. IR spectra of the samples were recorded over the range $4000-650 \mathrm{~cm}^{-1}$ on a PerkinElmer Spectrum One FT-IR spectrometer fitted with a UATR polarization accessory. Elemental analysis data were recorded at Science Centre, London Metropolitan University, 29 Hornsey Road, London N7 7DD, UK.

Magnetic studies. Magnetic susceptibility measurements were carried out on polycrystalline samples with a Quantum Design MPMS5 susceptometer working in the range 30-300 K under an external magnetic field of $0.3 \mathrm{~T}$ and under a field of $0.03 \mathrm{~T}$ in the $30-2 \mathrm{~K}$ range to avoid saturation effects. Diamagnetic corrections were estimated from Pascal tables.

Computational details. All calculations were performed using the Gaussian 09 program suite. ${ }^{51}$ The geometries of all stationary points located on the potential energy surfaces (PESs) were fully optimized without symmetry constraints, employing the 1997 hybrid functional of Perdew, Burke, and Ernzerhof $^{52-57}$ as implemented in the Gaussian 09 program suite. This functional uses $25 \%$ so-called "exact" exchange, i.e. Hartree-Fock-like exchange built on Kohn-Sham orbitals, $E_{\mathrm{x}}^{\mathrm{HF}}, 75 \%$ ("pure DFT") GGA exchange in the PBE approximation, $E_{\mathrm{x}}^{\mathrm{PBE}}$, and $100 \%$ GGA correlation in the PBE formulation, $E_{\mathrm{c}}^{\mathrm{PBE}}$ and is denoted as PBE0. For the geometry optimizations we have used the Def2-TZVP basis set for Co atoms and the 6-31G(d,p) basis set for all main group elements (E). Hereafter the method used in DFT calculations is abbreviated as PBE0/Def2-TZVP(Co) $\cup$ 6-31G(d,p)(E). All stationary points were identified as minima (number of imaginary frequencies Nimag $=0$ ). Acetonitrile solvent effects were taken into account with the polarizable continuum model (PCM) using the integral equation formalism variant (IEFPCM), the default self-consistent reaction field (SCRF) method. ${ }^{58}$

\section{Synthetic procedures}

Ligand synthesis. The synthesis of $\mathrm{HL}^{1}$ has been carried out according to the reported synthetic procedure. ${ }^{46}$

Synthesis of $\left[\mathrm{Co}^{I I} \mathrm{~L}_{2}{ }_{2}\right] \cdot 5 \mathrm{MeCN}(\mathbf{1} \cdot 5 \mathrm{MeCN}) .0 .55 \mathrm{mmol}(0.190$ g) of $\mathrm{HL}^{1}$ and $0.55 \mathrm{mmol}(77.1 \mu \mathrm{L})$ of $\mathrm{Et}_{3} \mathrm{~N}$ were dissolved in $20 \mathrm{ml}$ of MeCN. The resulting yellow solution was brought to reflux and stirred for 10 minutes. To this, $0.23 \mathrm{mmol}(0.050$ g) of $\mathrm{CoBr}_{2}$ were added and the resulting red solution was refluxed for another 20 minutes, filtered and kept in a vial and subjected to slow evaporation. Red crystals formed within 1 day. Yield: 35\% (based on Co). Selected IR peaks $\left(\mathrm{cm}^{-1}\right)$ : 2929 (w), $2820(\mathrm{w}), 1590$ (s), 1536 (m), 1492 (m), 1462 (m), 1434 (s), 1389 (s), 1300 (m), 1237 (m), 1209 (s), 1185(s), 1108 (m), 1080 (m), 1045 (m), 972 (m), 921 (w), 878 (w), 853 $(\mathrm{w}), 786(\mathrm{w}), 740(\mathrm{~s}), 702(\mathrm{~s}), 678(\mathrm{~m})$. Analogous reaction with $\mathrm{Co}\left(\mathrm{ClO}_{4}\right)_{2} \cdot 6 \mathrm{H}_{2} \mathrm{O}$ instead of $\mathrm{CoBr}_{2}$ at room temperature afforded a powder crystalline material which was found to be isostructural to 1 by determining the unit cell of the crystals and recording the IR spectra.

Synthesis of $\left[\mathrm{Ni}^{i \mathrm{II}} \mathrm{L}_{2}{ }_{2}\right] \cdot 5 \mathrm{MeCN}(2 \cdot 5 \mathrm{MeCN}) .0 .25 \mathrm{mmol}(0.084$ g) of $\mathrm{HL}^{1}$ and $0.25 \mathrm{mmol}(34.9 \mu \mathrm{L})$ of $\mathrm{Et}_{3} \mathrm{~N}$ were dissolved in $20 \mathrm{ml}$ of MeCN while stirring to produce a yellow solution. To this, $0.1 \mathrm{mmol}(0.037 \mathrm{~g})$ of $\mathrm{Ni}\left(\mathrm{ClO}_{4}\right)_{2} \cdot 6 \mathrm{H}_{2} \mathrm{O}$ were added. The resulting yellow solution was stirred for a further 15 minutes, filtered, and then kept in a vial and stored at room temperature. Large green needles were obtained after 2 days. Yield: 55\% (based on Ni). Selected IR peaks $\left(\mathrm{cm}^{-1}\right): 2927(\mathrm{w})$, 2822 (w), 2247 (w), 1593 (s), 1541 (m), 1496 (m), 1450 (m), 1438 (s), 1393 (m), 1298 (m), 1242 (m), 1208 (s), 1185(s), 1109 (m), 1076 (m), 1047 (m), 974 (s), $922(\mathrm{w}), 878(\mathrm{w}), 847(\mathrm{w})$, $820(\mathrm{w}), 781(\mathrm{w}), 741(\mathrm{~s}), 702(\mathrm{~s}), 686(\mathrm{~m})$. 
Synthesis of $\left[\mathrm{Cu}^{I I} \mathrm{~L}_{2}{ }_{2}\right] \cdot \mathrm{MeCN}(3 \cdot \mathrm{MeCN}) .0 .25 \mathrm{mmol}(0.084 \mathrm{~g})$ of $\mathrm{HL}^{1}$ and $0.5 \mathrm{mmol}(69.0 \mu \mathrm{L})$ of $\mathrm{Et}_{3} \mathrm{~N}$ were dissolved in 20 $\mathrm{ml}$ of MeCN while stirring to produce a yellow solution. To this, $0.1 \mathrm{mmol}(0.020 \mathrm{~g})$ of $\mathrm{Cu}(\mathrm{OAc})_{2} \cdot \mathrm{H}_{2} \mathrm{O}$ were added. The resulting dark brown solution was stirred for a further 15 minutes, filtered, and then kept in a vial and stored at room temperature. Dark brown block crystals were obtained after 1 day. Yield: 45\% (based on $\mathrm{Cu}$ ). Selected IR peaks $\left(\mathrm{cm}^{-1}\right): 2932$ (w), 2830 (w), 1662 (s), 1583 (s), 1538 (m), 1492 (m), 1456 (s), 1434 (m), 1389 (m), 1298 (m), 1242 (m), 1208 (s), 1155 (w), 1109 (m), 1073 (s), 1043 (s), 976 (s), 928 (w), 878 (w), 850 (w), $820(\mathrm{w}), 789(\mathrm{~m}), 742(\mathrm{~s}), 707(\mathrm{~s}), 688(\mathrm{~m})$. Elemental analysis

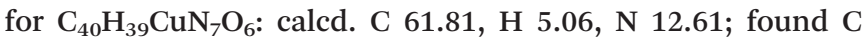
61.67, H 5.27, N 12.51.

Synthesis of $\left[\mathrm{Co}^{\mathrm{II}}{ }_{4} \mathrm{~L}_{4}{ }_{4}(\mathrm{MeO})_{2}\right] \cdot 2\left(\mathrm{ClO}_{4}\right)$ (4). $0.25 \mathrm{mmol}(0.084$ g) of $\mathrm{HL}^{1}$ and $0.25 \mathrm{mmol}(34.9 \mu \mathrm{L})$ of $\mathrm{Et}_{3} \mathrm{~N}$ were dissolved in $20 \mathrm{ml} \mathrm{MeOH}$ while stirring to produce a yellow solution. To this, $0.1 \mathrm{mmol}(0.037 \mathrm{~g})$ of $\mathrm{Co}\left(\mathrm{ClO}_{4}\right)_{2} \cdot 6 \mathrm{H}_{2} \mathrm{O}$ were added. The resulting red solution was stirred for a further 15 minutes, filtered, and then kept in a vial and stored at room temperature. Red prismatic crystals were obtained after 5 days. Yield: $25 \%$ (based on Co). Selected IR peaks $\left(\mathrm{cm}^{-1}\right)$ : 2935 (w), 2817 (w), 1603 (s), 1583 (s), 1558 (m), 1544 (m), 1489 (w), 1456 (s), 1433 (s), 1391 (m), 1241 (m), 1213 (s), 1194 (m), 1081 (s), 1036 (s), 969 (s), 913 (w), 869 (w), 855 (w), $788(\mathrm{~m}), 741(\mathrm{~s}), 701(\mathrm{~s}), 677(\mathrm{~m})$.

Synthesis of $\left[\mathrm{Co}^{\mathrm{II}}{ }_{4} \mathrm{~L}_{4}{ }_{4}\left(\mathrm{H}_{2} \mathrm{O}\right)_{4}\right]$ (5). $0.30 \mathrm{mmol}(0.100 \mathrm{~g})$ of $\mathrm{HL}^{1}$ and $0.30 \mathrm{mmol}(41.8 \mu \mathrm{L})$ of $\mathrm{Et}_{3} \mathrm{~N}$ were dissolved in $20 \mathrm{ml}$ MeCN while stirring to produce a yellow solution. To this, $0.24 \mathrm{mmol}(0.060 \mathrm{~g})$ of $\mathrm{Co}(\mathrm{OAc})_{2} \cdot 4 \mathrm{H}_{2} \mathrm{O}$ were added. The resulting red solution was stirred for a further 20 minutes, filtered, and then kept in a vial and stored at room temperature. Red block crystals were obtained after 3 days. Yield: 20\% (based on Co). Selected IR peaks $\left(\mathrm{cm}^{-1}\right): 2929(\mathrm{w})$, 2834 (w), 1623 (s), 1592 (s), 1540 (m), 1497 (m), 1440 (s), 1404 (m), 1311 (m), 1235 (m), 1209 (s), 1072 (s), 1024 (s), 971 (s), $877(\mathrm{w}), 857(\mathrm{w}), 787(\mathrm{w}), 738(\mathrm{~s}), 722(\mathrm{~s}), 684(\mathrm{~m})$.

Synthesis of $\left[\mathrm{Co}^{\mathrm{II}}{ }_{4} \mathrm{~L}_{4}{ }_{4}\left(\mathrm{H}_{2} \mathrm{O}\right)_{4}\right]$ (6). Method 1: (6) was prepared in the same ratio and solvent as (3) by using $\mathrm{Co}(\mathrm{OAc})_{2} \cdot 4 \mathrm{H}_{2} \mathrm{O}$ and then carefully layering the solution over $\mathrm{Et}_{2} \mathrm{O}$ at a respective ratio of $1: 2$. Red block crystals were obtained after 1 day. Yield: 35\% (based on Co). Selected IR peaks (cm ${ }^{-1}$ ): 2935 (w), 2828 (w), 1621 (s), 1592 (s), 1544 (m), 1494 (m), 1445 (s), 1403 (m), 1307 (m), 1239 (m), 1210 (s), 1074 (s), 1026 (s), 967 (s), 875 (w), 856 (w), 811 (w), 737 (s), 719 (s), 690 (m). Method 2: $0.56 \mathrm{mmol}(0.190 \mathrm{~g})$ of L and 1.11 mmol $(154.3 \mu \mathrm{L})$ of $\mathrm{Et}_{3} \mathrm{~N}$ were dissolved in $20 \mathrm{ml} \mathrm{MeCN}$. The resulting yellow solution was brought to reflux and stirred for 10 minutes. To this, $0.46 \mathrm{mmol}(0.157 \mathrm{~g})$ of $\mathrm{Co}\left(\mathrm{BF}_{4}\right)_{2} \cdot 6 \mathrm{H}_{2} \mathrm{O}$ were added and the resulting red solution was refluxed for another 20 minutes, filtered and kept in a vial and subjected to slow evaporation. Red crystals formed within 1 day. Yield: 20\% (based on Co). Method 3: $0.56 \mathrm{mmol}$ (0.190 g) of $\mathrm{L}$ and $2.21 \mathrm{mmol}(308.6 \mu \mathrm{L})$ of $\mathrm{Et}_{3} \mathrm{~N}$ were dissolved in $20 \mathrm{ml} \mathrm{MeCN}$. The resulting yellow solution was brought to reflux and stirred for 10 minutes. To this, $0.45 \mathrm{mmol}(0.166 \mathrm{~g})$ of
$\mathrm{Co}\left(\mathrm{ClO}_{4}\right)_{2} \cdot 6 \mathrm{H}_{2} \mathrm{O}$ were added and the resulting red solution was refluxed for another 20 minutes, filtered and kept in a vial and subjected to slow evaporation. Red crystals formed within 1 day. Yield: $20 \%$ (based on Co). Elemental analysis for $\mathrm{C}_{76} \mathrm{H}_{76} \mathrm{Co}_{4} \mathrm{~N}_{12} \mathrm{O}_{24}$ : calcd. C 51.37, $\mathrm{H} \mathrm{4.31,} \mathrm{N}$ 9.46; found $\mathrm{C}$ 47.67, $\mathrm{H} \mathrm{4.15,} \mathrm{N}$ 8.74. This result corresponds to the presence of eight water molecules. $\mathrm{C}_{76} \mathrm{H}_{76} \mathrm{Co}_{4} \mathrm{~N}_{12} \mathrm{O}_{24}\left(\mathrm{H}_{2} \mathrm{O}\right)_{8}$ : $\mathrm{C} 47.49, \mathrm{H}$ 4.82, $\mathrm{N}$ 8.75. The crystalline material collected using Methods 2 and 3 was found to be isostructural to that collected using Method 1 by determining the unit cell of the crystals and recording the IR spectra.

Synthesis of $\left[\mathrm{Co}^{I I I} \mathrm{~L}^{1} \mathrm{~L}^{4}\right] \cdot 2 \mathrm{MeCN}$ (7.2MeCN). Compound 7 was prepared in the same ratio, metal salt and solvent as (5) by refluxing the solution for 20 minutes. The resulting red solution was then filtered and kept in a vial stored at room temperature. Red block crystals were obtained after 3 days. Yield: $30 \%$ (based on Co). Selected IR peaks $\left(\mathrm{cm}^{-1}\right)$ : $2935(\mathrm{w})$, 1639 (s), 1621 (s), 1591 (s), 1547 (m), 1492 (m), 1442 (s), 1401 (m), 1302 (m), 1238 (m), 1213 (s), 1077 (s), 1028 (s), 968 (s), $875(\mathrm{w}), 856(\mathrm{w}), 811(\mathrm{w}), 737(\mathrm{~s}), 719(\mathrm{~s}), 690(\mathrm{~m})$.

Synthesis of $\left[\mathrm{Ni}_{2}{ }_{2} \mathrm{~L}^{1}{ }_{3}(\mathrm{MeOH})\right] \cdot\left(\mathrm{ClO}_{4}\right) \cdot 2 \mathrm{MeOH} \quad(8 \cdot 2 \mathrm{MeOH})$. Compound 8 was prepared in the same ratio and solvent as (4) by using $\mathrm{Ni}\left(\mathrm{ClO}_{4}\right)_{2} \cdot 6 \mathrm{H}_{2} \mathrm{O}$ and then keeping the filtered solution in a vial stored at room temperature. Large dark yellow crystals were obtained after 2 days. Yield: 35\% (based on Ni). Selected IR peaks ( $\left.\mathrm{cm}^{-1}\right)$ : 2935 (w), 2816 (w), 1603 (s), 1585 (s), 1559 (m), 1543 (m), 1492 (w), 1453 (s), 1436 (s), 1391 (m), 1241 (m), 1213 (s), 1193 (m), 1081 (s), 970 (s), 913 (w), $856(\mathrm{w}), 789(\mathrm{~m}), 741$ (s), 701 (s), 677 (m). Elemental analysis for $\mathrm{C}_{60} \mathrm{H}_{66} \mathrm{ClN}_{9} \mathrm{Ni}_{2} \mathrm{O}_{16}$ : calcd. C 54.51, H 5.03, N 9.53; found $\mathrm{C}$ 54.33, $\mathrm{H}$ 4.88, $\mathrm{N} 9.41$.

Synthesis of $\left[\mathrm{Cu}^{\mathrm{II}}{ }_{4} \mathrm{~L}_{4}{ }_{4}(\mathrm{MeO})_{2}\right] \cdot 2\left(\mathrm{ClO}_{4}\right) \cdot 6 \mathrm{MeOH} \quad(9 \cdot 6 \mathrm{MeOH})$. $0.1 \mathrm{mmol}(0.034 \mathrm{~g})$ of $\mathrm{HL}^{1}$ and $0.1 \mathrm{mmol}(13.9 \mu \mathrm{L})$ of $\mathrm{Et}_{3} \mathrm{~N}$ were dissolved in $20 \mathrm{ml}$ of $\mathrm{MeOH}$ while stirring to produce a yellow solution. To this, $0.2 \mathrm{mmol}(0.074 \mathrm{~g})$ of $\mathrm{Cu}\left(\mathrm{ClO}_{4}\right)_{2}$ $\cdot 6 \mathrm{H}_{2} \mathrm{O}$ were added. The resulting dark green solution was stirred for a further 20 minutes, filtered, and then kept in a vial stored at room temperature. Brown block crystals were obtained after 2 days. Yield: $20 \%$ (based on $\mathrm{Cu}$ ). Selected IR peaks (cm $\left.{ }^{-1}\right)$ : 2939 (w), 2817 (w), 1603 (s), $1576(\mathrm{~s}), 1558(\mathrm{~m})$, 1548 (m), 1492 (w), 1451 (s), 1433 (s), 1391 (m), 1241 (m), 1213 (s), 1195 (m), 1081 (s), 974 (s), 916 (w), 869 (w), 855 (w), $791(\mathrm{~m}), 742(\mathrm{~s}), 701(\mathrm{~s}), 677(\mathrm{~m})$. Elemental analysis for $\mathrm{C}_{84} \mathrm{H}_{102} \mathrm{Cl}_{2} \mathrm{Cu}_{4} \mathrm{~N}_{12} \mathrm{O}_{28}$ : calcd. $\mathrm{C} 42.15, \mathrm{H} 4.01, \mathrm{~N} 8.19$; found $\mathrm{C}$ 41.50, H 4.04, N 7.62.

\section{Crystallography}

Data for 1, 2, 3, 5, 6, 9 and 10 were collected ( $\omega$-scans) at the University of Sussex using an Agilent Xcalibur Eos Gemini Ultra diffractometer with a CCD plate detector under a flow of nitrogen gas at $173(2) \mathrm{K}$ using Mo $\mathrm{K} \alpha$ radiation $(\lambda=$ $0.71073 \AA$ ). CrysAlis CCD and RED software were used for data collection and processing, respectively. Reflection intensities were corrected for absorption by the multi-scan method. Data for 4,7 and 8 were collected at the National 
Crystallography Service, University of Southampton. ${ }^{59}$ All structures were determined using Olex $2,{ }^{60}$ solved using either Superflip $^{61}$ or SHELXT ${ }^{62,63}$ and refined with SHELXL-2014. ${ }^{64}$ All non-H atoms were refined with anisotropic thermal parameters, and $\mathrm{H}$ atoms were introduced at calculated positions and allowed to ride on their carrier atoms. In compounds 8 and 9, atoms of minor components (several with partial occupancy) were sensibly refined isotropically. Crystal data and structure refinement parameters for all compounds are given in Tables S1 and S2. $\dagger$ Geometric/crystallographic calculations were performed using PLATON, ${ }^{65}$ Olex $2,{ }^{60}$ and WINGX $^{62}$ packages; graphics were prepared with Crystal Maker and MERCURY. ${ }^{66}$

\section{Results and discussion}

\section{Crystal structure description}

Compounds 1-3 are monomers synthesized using a $4: 5: 5$, $2: 5: 10$ or $2: 5: 5$ metal-ligand-base ratio and acetonitrile as solvent (Fig. 1). All compounds crystallize in the triclinic $P \overline{1}$ space group and contain one molecule in the asymmetric unit. Compounds 1 and 2 are isostructural and thus only the former will be further described. Compound 1 is a $\mathrm{Co}^{\mathrm{II}}$ monomer in which the metal centre has a distorted octahedral geometry, coordinating to two ligand molecules and a total of 6 atoms. Each ligand coordinates to $\mathrm{Co}^{\mathrm{II}}$ via the phenoxide oxygen atoms ( $\mathrm{O} 2$ and $\mathrm{O} 5)$, the imine group nitrogen atoms (N1 and N4) and the carbonyl group oxygen atoms (O3 and O6) (Scheme S1, $\dagger$ mode A). The mean $\mathrm{M}-\mathrm{O}_{\text {phenoxide }}$ distances are 2.0076(17) and 2.0141(16) $\AA$, while the $\mathrm{M}-\mathrm{N}_{\text {imine }}$ distances were measured at 2.0873(19) and 2.0855(18) Å. M$\mathrm{O}_{\text {carbonyl }}$ distances are slightly longer at 2.2458(16) and 2.2286(16) A, respectively, indicative of a $\mathrm{Co}^{\mathrm{II}}$. Similar bond distances for 2 can be found in the $\operatorname{ESI}^{\dagger} \uparrow$ (Table S3). Five acetonitrile molecules are also present in the crystal lattice. Each molecule is isolated within the crystal structure as there are no hydrogen bonds or other supramolecular interactions formed.

Compound 3 is a $\mathrm{Cu}$ monomer in which the metal centre coordinates to two ligand molecules and a total of 4 atoms, having a distorted square planar geometry. Each ligand coordinates to $\mathrm{Cu}^{\mathrm{II}}$ via the phenoxide oxygen atoms (O2 and $\mathrm{O} 5$ ) and the imine group nitrogen atoms (N1 and N4) (Scheme
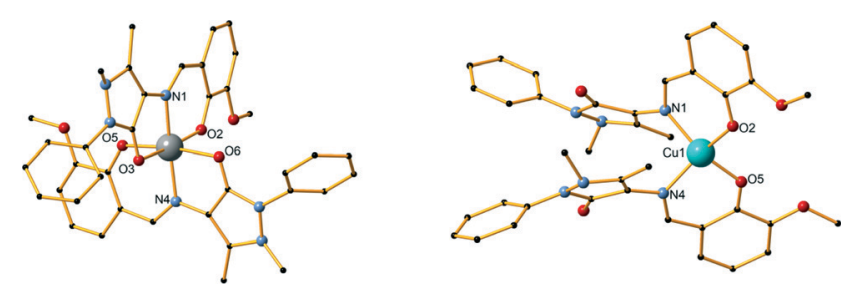

Fig. 1 (Left) The structure of compounds 1 and 2. $\mathrm{M}=\mathrm{Co}^{\prime \prime}$ (1), $\mathrm{Ni}^{\prime \prime}$ (2). (Right) The structure of compound 3. $\mathrm{H}$ atoms and solvent molecules are omitted for clarity. Colour code: $\mathrm{M}$, grey; $\mathrm{Cu}$, light blue; $\mathrm{O}$, red; $\mathrm{C}$, black; N, blue.
$\mathrm{S} 1, \uparrow$ mode $\mathrm{B})$. The mean $\mathrm{M}-\mathrm{O}_{\text {phenoxide }}$ distances are 1.8991(13) $\AA$ and 1.9006(14) $\AA$, while the $\mathrm{M}-\mathrm{N}_{\text {imine }}$ distances were measured at $1.9671(14)$ and $1.9532(17) \AA$, all slightly lower than the respective distances in compounds 1 and 2 . One acetonitrile molecule is also present in the crystal lattice. As in 1 and 2, no hydrogen bonding or other supramolecular interaction can be found within the crystal structure.

Compound 4 is synthesized using a 2:5:5 metal-ligandbase ratio and methanol as solvent and crystallizes in the monoclinic $P 2_{1} / c$ space group. The asymmetric unit contains
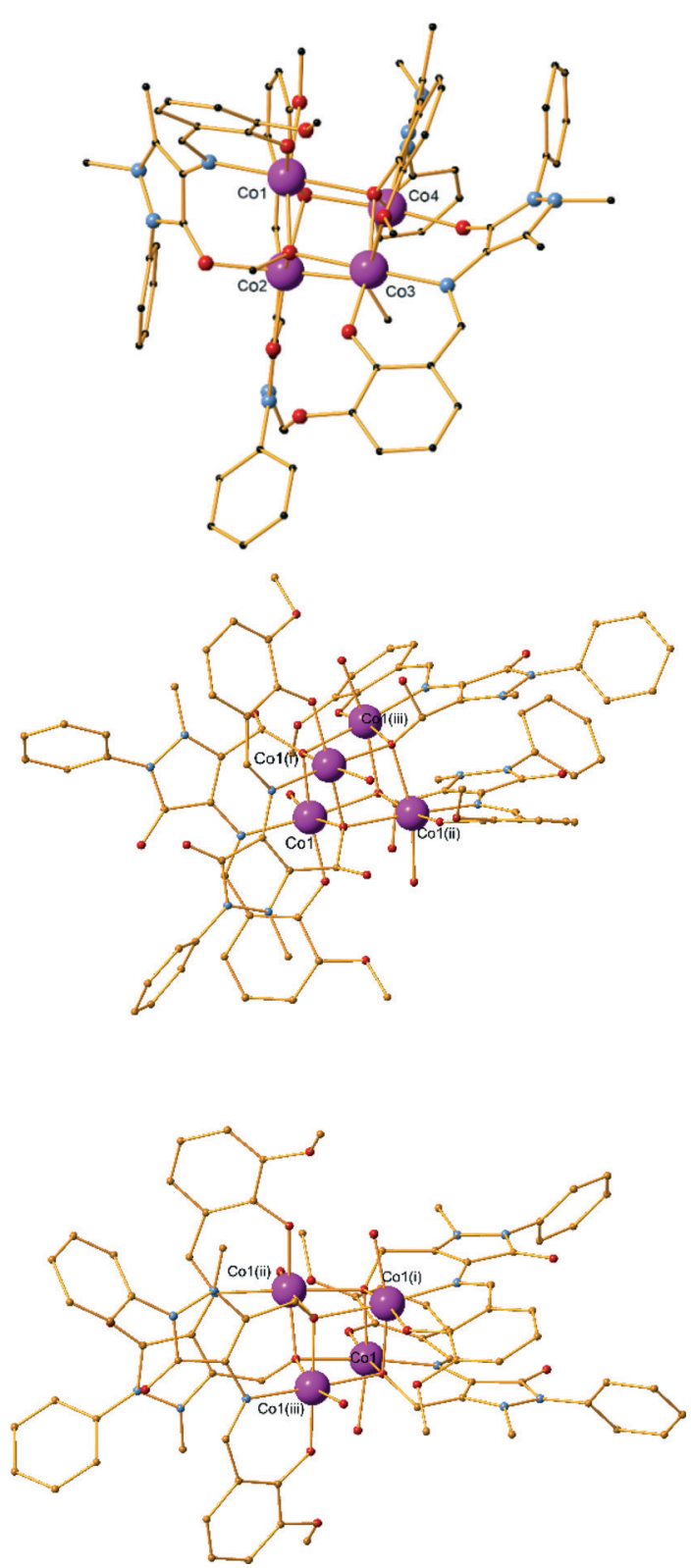

Fig. 2 The structure of compounds 4 (top) and 5 (middle). Symmetry operations: (i) $1-x, 3 / 2-y, z$; (ii) $5 / 4-y, 1 / 4+x, 1 / 4-z$; (iii) $y-1 / 4,5 /$ $4-x, 1 / 4-z$. (Bottom) The structure of compound 6 . Symmetry operations: (i) $1-x, 3 / 2-y, z$; (ii) $y-1 / 4,5 / 4-x, 5 / 4-z$; (iii) $5 / 4-y, 1 /$ $4+x, 5 / 4-z$. $\mathrm{H}$ atoms and lattice molecules are omitted for clarity. Colour code: Co, purple; O, red; C, black; N, blue. 
four metal centres, four ligand molecules, two bridging methoxides and two perchlorate counter ions (Fig. 2, top).

The main core of the cluster is a deformed cubane-like $\mathrm{Co}_{4} \mathrm{O}_{4}$ consisting of four $\mathrm{Co}^{\mathrm{II}}$ centres, two bridging $\mu_{3}-\mathrm{O}$ methoxido atoms, and two bridging $\mu_{3}-\mathrm{O}$ phenoxido atoms. Each of the $\mathrm{Co}^{\mathrm{II}}$ centres coordinates to six atoms and displays a distorted octahedral geometry. The four organic ligands exhibit two different coordination modes, two ligands per mode. In the first mode, the phenoxide oxygen atom and the imine nitrogen atom coordinate to one $\mathrm{Co}^{\mathrm{II}}$ centre, while the carbonyl oxygen atom coordinates to a second $\mathrm{Co}^{\mathrm{II}}$ centre (Scheme $\mathrm{S} 1, \dagger$ mode $\mathrm{C}$ ). In the second mode, one $\mathrm{Co}^{\mathrm{II}}$ centre is coordinated to the phenoxide oxygen atom, the imine nitrogen atom and the carbonyl oxygen atom, while the phenoxide atom is further bridging two $\mathrm{Co}^{\mathrm{II}}$ centres and the methyl ether group oxygen atom also coordinates to the third $\mathrm{Co}^{\mathrm{II}}$ centre (Scheme S1, $\uparrow$ mode D). The $\mathrm{Co}^{\mathrm{II}} \cdots \mathrm{Co}^{\mathrm{II}}$ distances range from 3.018(7) to 3.350(7) Å. Selected bond lengths and angles for 4 are given in Table S10.† No hydrogen bonds or other supramolecular interactions can be found between the molecules within the crystal structure.

Compound 5 is synthesized using a 4:5:5 metal-ligandbase ratio and acetonitrile as solvent (Fig. 2, middle). As in 4, a $\mathrm{Co}_{4}{ }_{4} \mathrm{O}_{4}$ cubane-like core is formed; however, a transformation of the ligand has taken place. $\mathrm{The}^{\mathrm{CH}_{3}}$ group of the $\mathrm{C}$ atom of the pyrazolone ring is oxidized to a $\mathrm{CH}_{2} \mathrm{OH}$, as confirmed by X-ray crystallography (Scheme 1, $\mathrm{H}_{2} \mathrm{~L}^{2}$ ). Compound 5 has crystallographically imposed $\overline{4}$ symmetry and crystallizes in the tetragonal $I 4_{1} / a$ space group and the asymmetric unit consists of one $\mathrm{Co}^{\mathrm{II}}$ centre, one $\mathrm{L}^{2}$ ligand and one water molecule. There are no solvent molecules or counter ions present in the structure. The cubane-like $\mathrm{Co}_{4}^{\mathrm{II}}{ }_{4} \mathrm{O}_{4}$ consists of the four $\mathrm{Co}^{\mathrm{II}}$ and four bridging $\mu_{3}-\mathrm{O}$ methoxido atoms of the $\mathrm{CH}_{2} \mathrm{OH}$ transformed group. Only one type of coordination mode is present in the structure, as the ligand coordinates to the metal centre via the imine nitrogen atom (N1), the phenoxide oxygen atom $(\mathrm{O} 2)$ and the $\mathrm{CH}_{2} \mathrm{OH}$ transformed group oxygen atom (O4) (Scheme $\mathrm{S} 1, \uparrow$ mode $\mathrm{G}$ ). A water molecule also coordinates to each of the cobalt centres, thus fulfilling its distorted octahedral geometry. The mean $\mathbf{M}-\mathbf{N}_{\text {imine }}$ distance was measured at 2.110(2) $\AA$, which is the longest M$\mathrm{N}_{\text {imine }}$ bond observed in this study. Co $\cdots$ Co distances range from 3.2064(10) to 3.2157(6) ^. Additional bond distances and angles are given in Table S10 $\dagger$ The crystal structure of 5 is stabilized by a strong $\mathrm{O}-\mathrm{H} \cdots \mathrm{O}$ intermolecular hydrogen bond which involves a water oxygen atom (O5) as a donor and the phenoxide oxygen atom $(\mathrm{O} 2)$ as an acceptor. The parameters of this hydrogen bond can be found in Table S4. $\dagger$ Compound 6 has crystallographically imposed $\overline{4}$ symmetry and is isoskeletal to 4 and 5 . It was synthesized using a $2: 5$ : 10 metal-ligand-base ratio and acetonitrile as solvent (Fig. 2, right). Reactions with different conditions under a $4: 5: 10$ and a $4: 5: 20$ ratio afforded the same product but in a lower yield. As in 4 and 5 , a $\mathrm{Co}_{4}{ }_{4} \mathrm{O}_{4}$ cubane-like core is formed; however, a different transformation of the ligand is observed. The methyl group connected to the pyrazolone ring is, in the present case, transformed to a $\mathrm{CH}(\mathrm{OH})_{2}$ group (Scheme 1, $\mathrm{H}_{3} \mathrm{~L}^{3}$ ). The two $\mathrm{C}-\mathrm{O}$ bonds were crystallographically refined, without any restrictions, to 1.346(7) and 1.398(4) $\AA$ for O4 and $\mathrm{O5}$, respectively, typical of a single $\mathrm{C}-\mathrm{O}$ bond value. The compound crystallizes in the tetragonal $I 4_{1} / a$ space group and the asymmetric unit consists of one $\mathrm{Co}^{\mathrm{II}}$ centre, one $\mathrm{L}^{3}$ ligand and one water molecule. There are no solvent molecules or counter ions present in the structure. The cubanelike $\mathrm{Co}_{4}^{\mathrm{II}} \mathrm{O}_{4}$ consists of the four $\mathrm{Co}^{\mathrm{II}}$ centres and four bridging $\mu_{3}-\mathrm{O}$ atoms; the oxygen atom belongs to the transformed $\mathrm{CH}(\mathrm{OH})_{2}$ group. Only one type of coordination mode is present in the structure, as the ligand coordinates to the metal centre via the imine nitrogen atom (N1), the phenoxide oxygen atom $(\mathrm{O} 2)$ and an oxygen atom (O4) (Scheme $\mathrm{S} 1, \dagger$ mode $\mathrm{H}$ ).

A water molecule also coordinates to each of the cobalt centres to fulfil the distorted octahedral geometry. The mean M-N $\mathrm{N}_{\text {imine }}$ distance was measured at 2.107(3) ̊. Co $\cdots$ Co distances range from 3.2207(11) to 3.2277(9) Å. Additional bond distances and angles are given in Table S10.† The crystal structure of 6 is stabilized by a strong $\mathrm{O}-\mathrm{H} \cdots \mathrm{O}$ intermolecular hydrogen bond, which involves a water oxygen atom (O6) as a donor and a carbonyl oxygen atom (O3) as an acceptor. The structure is further stabilized by a strong O$\mathrm{H} \cdots \mathrm{O}$ intramolecular hydrogen bond within two ligands, in which an oxygen atom of the transformed group (O5) participates as a donor. The parameters of these hydrogen bonds are listed in Table $55 . \dagger$

Compound 7 was synthesized using a 4:5:5 metalligand-base ratio and acetonitrile as solvent (Fig. 3). It crystallizes in the triclinic $P \overline{1}$ space group and contains two molecules in the asymmetric unit. Unlike the three previous structures, bond valence sum (BVS) calculations ${ }^{67}$ are indicative of oxidation state III for both Co centres (3.22 for Co1 and 3.24 for Co2). The ligand undergoes another oxidation $\left(\mathrm{H}_{2} \mathrm{~L}_{4}\right.$, Scheme 1) and the methyl group connected to the pyrazolone ring is transformed to a carboxylate, as assigned by the

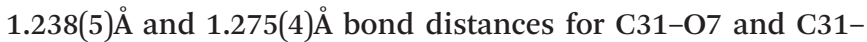
O6, respectively. Each molecule contains a $\mathrm{Co}^{\mathrm{III}}$ centre, one $\mathrm{L}^{1}$ ligand and one $\mathrm{L}^{4}$ ligand as well as two acetonitrile solvent

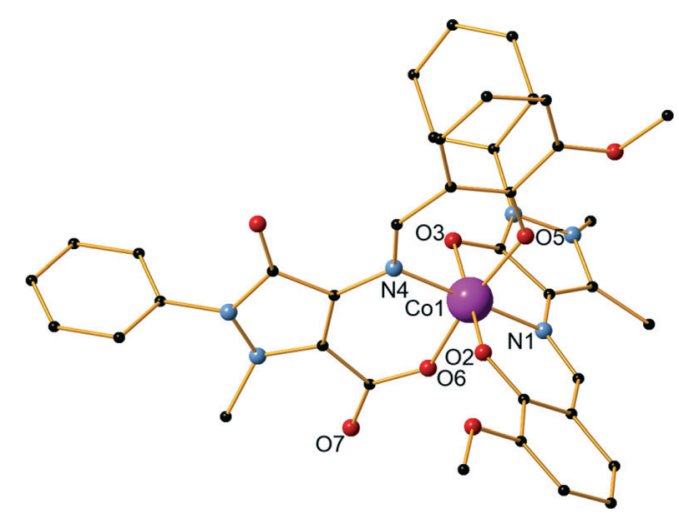

Fig. 3 The structure of compound 7. $\mathrm{H}$ atoms and solvent molecules are omitted for clarity. Color code: Co, pink; O, red; C black; N, blue. 
molecules. The $\mathrm{Co}^{\mathrm{III}}$ centre has a distorted octahedral geometry and is coordinated to one $\mathrm{L}^{1}$ molecule via the phenoxide oxygen atom, the imine group nitrogen atom and the carbonyl group oxygen atom (Scheme $\mathrm{S} 1, \dagger$ mode $\mathrm{A}$ ) as well as one $\mathrm{L}^{4}$ molecule via the imine nitrogen atom, the phenoxide oxygen atom and the carboxyl group oxygen atom (Scheme S1, $\dagger$ mode I). The mean $\mathbf{M}-\mathrm{N}_{\text {imine }}$ distances are relatively similar for both ligands (1.929(3) $\AA$ for $\mathrm{L}^{4}$ coordination, 1.933(3) and 1.937(3) $\AA$ for $\mathrm{L}^{1}$ coordination), while the $\mathrm{M}-\mathrm{O}_{\text {phenoxide }}$ distances are smaller in the case of the $\mathrm{L}^{1}$ ligand (1.869(3) $\AA$ for $\mathrm{L}^{1}$ coordination, 1.873(3) and 1.885(3) $\AA$ for $\mathrm{L}^{4}$ coordination). The mean $\mathrm{M}-\mathrm{O}_{\text {carbonyl }}$ distances are 1.970(3) and 1.985(3) A, significantly larger than the $\mathbf{M}-\mathrm{O}_{\text {carboxyl }}$ distances which were measured at 1.904(3) and 1.912(3) A. Two acetonitrile molecules are also present in the crystal lattice. As in the previous monomeric compounds (1-3), there are no hydrogen bonds or other supramolecular interactions formed between the molecules within the crystal structure.

Compound 8 is a Ni dimer, synthesized using a 2:5:5 metal-ligand-base ratio and methanol as solvent (Fig. 4). It crystallizes in the monoclinic $I 2 / c$ space group and contains one molecule in the asymmetric unit. Each nickel centre is coordinated to six atoms and displays a distorted octahedral geometry. There are three ligand molecules in the structure and each exhibits a different coordination mode (Scheme 1, $\dagger$ modes A, E, and F). Ni1 is coordinated to two ligands, while $\mathrm{Ni} 2$ is coordinated to all three. In detail, Ni1 is coordinated to the carbonyl oxygen atom of one ligand (O6) and the imine nitrogen atoms (N4, N7) as well as the phenoxide oxygen atoms (O5, O8) of two ligand molecules. A terminal methanol solvent molecule also coordinates to the metal centre through the oxygen atom $\mathrm{O} 10 \mathrm{Ni} 2$ is coordinated to phenoxide oxygen atoms from all three ligands (O2, O5, O8), the imine nitrogen atom and the phenoxide oxygen atom of one ligand ( $\mathrm{N} 1$ and $\mathrm{O} 3$, respectively), as well as the methyl ether group oxygen atom of a second ligand molecule (O4). Out of the respective $\mathrm{Ni}-\mathrm{O}$ distances, $\mathrm{Ni2}-\mathrm{O} 4$ was the longest and was measured at 2.295(3) $\AA$, while Ni1-O5 was the shortest at 1.984(3) A. Comparing the respective $\mathrm{Ni}-\mathrm{N}$ distances, the mean Ni1-N4 distance was the longest at 2.085(3) $\AA$, while

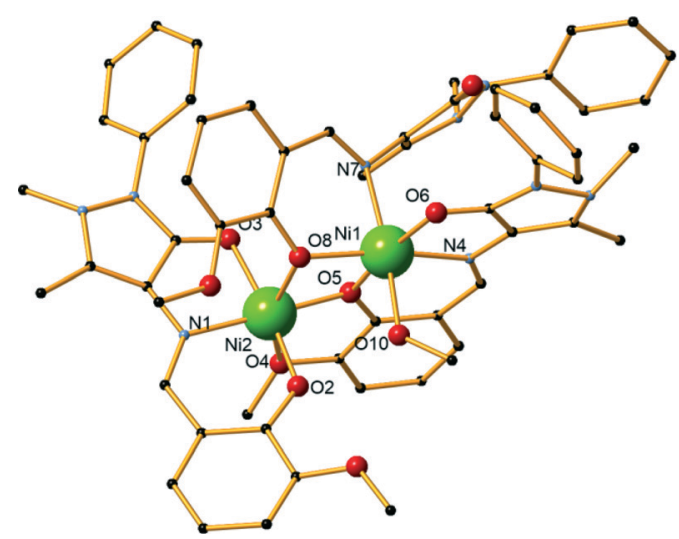

Fig. 4 The structure of compound 8 . $\mathrm{H}$ atoms and lattice molecules are omitted for clarity. Color code: $\mathrm{Ni}$, green; $\mathrm{O}$, red; C, black; $\mathrm{N}$, blue.
Ni2-N1 was the shortest at 2.020(3) A. Selected bond lengths and angles are given in the ESI $\dagger$ (Table S6). Two perchlorate counter ions are also present in the structure along with two lattice solvent molecules. The crystal structure of $\mathbf{8}$ is stabilized by strong $\mathrm{O}-\mathrm{H} \cdots \mathrm{O}$ intermolecular hydrogen bonds, which are formed between either two lattice methanol molecules or one lattice methanol and a perchlorate anion. Further stabilization occurs with the formation of a strong O$\mathrm{H} \cdots \mathrm{O}$ intramolecular hydrogen bond within the ligands. The parameters of these hydrogen bonds are listed in Table S7. $\dagger$ Compound 9 is synthesized using a 4:2:2 metal-ligand-base ratio and methanol as solvent and is isoskeletal ${ }^{68}$ to compound 4 previously described in detail. Bond angles and distances can be found in the ESI $\dagger$ (Tables S8 and S9).

\section{Topological features}

$\mathrm{HL}^{1}$ offers similar coordination environment to other diprotic ligands; however, in order to identify its unique and different coordination abilities we performed an extended literature CSD search $^{43}$ seeking the coordination abilities of any ligand that resembles those in Scheme 2, bottom. Then, we further categorized these findings employing our topological approach to describe CCs, ${ }^{69}$ which resulted in a library of all CCs with nuclearity over 3 (ESI, $\dagger$ Excel). The library consists of 100 CCs possessing 29 different motifs. Only 28 entries contain solely 3d ( $\mathrm{Mn}, \mathrm{Fe}, \mathrm{Co}, \mathrm{Ni}$ and $\mathrm{Cu}$ ) metal centres. Utilizing $\mathrm{HL}^{1}$ along with $\mathrm{Co}^{\mathrm{II}}$ and $\mathrm{Cu}^{\mathrm{II}}$, in methanolic solution, results in cubane $\mathrm{Co}_{4}{ }^{\mathrm{II}}$ (4) and $\mathrm{Cu}_{4}{ }^{\mathrm{II}}$ (9) structures (3M4-1, Scheme 2), ${ }^{69}$ in the presence of $\mathrm{MeO}$ bridges, and along with $\mathrm{Ni}\left(\mathrm{ClO}_{4}\right)_{2} \cdot 6 \mathrm{H}_{2} \mathrm{O}$ in a Ni${ }^{\mathrm{II}}$ dimer $(8)(\mathbf{M} 2-1$, Scheme 2$)$. In contrast, the reaction of diprotic ligands with $\mathrm{Ni}$ results in $\mathrm{a} \mathrm{Ni}_{4}{ }_{4}$

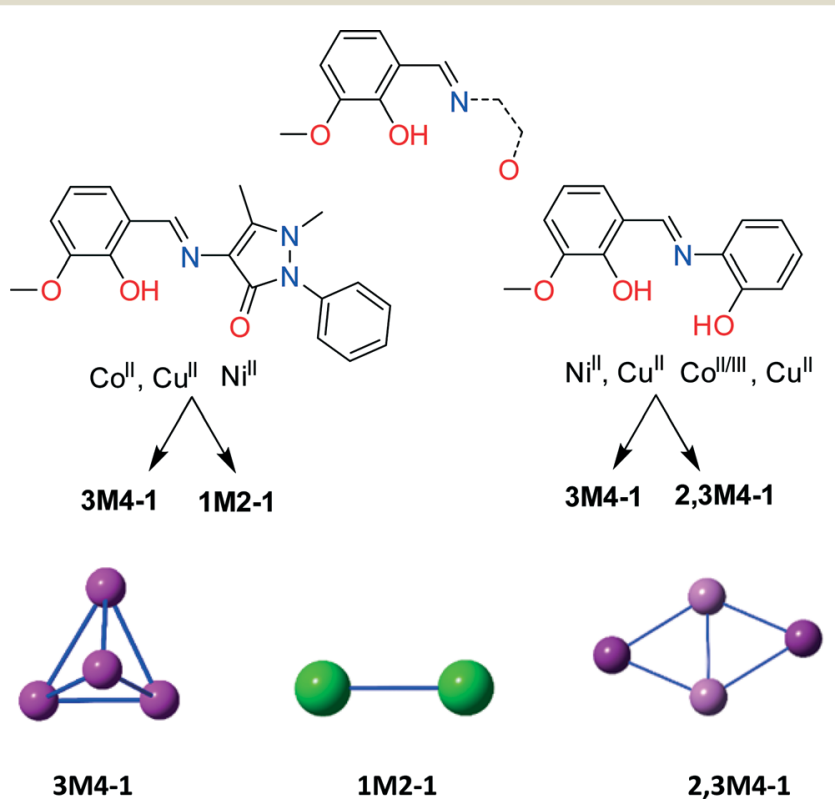

Scheme 2 (Top) A drawing of the organic molecules with similar coordination environment to $\mathrm{HL}^{1}$ used for the CSD search. (Bottom) A cartoon representation of the $\mathrm{Co}-, \mathrm{Ni}-$, and $\mathrm{Cu}$-based $\mathrm{CCs}$ obtained using different ligands, indicated in the centre, and their motif. 
cubane (3M4-1), ${ }^{30}$ built solely by the organic ligand, while $\mathrm{Cu}$ forms either a defective dicubane ${ }^{70}$ (2,3M4-1, Scheme 2) or a cubane (3M4-1) motif. ${ }^{4,71}$ No data were found for Co chemistry, and thus for a structural comparison, we performed the reaction of the diprotic ligand $[(E)-2-(2-$ hydroxy-3-methoxybenzylidene-amino)phenol, $\left.\mathrm{H}_{2} \mathrm{~L}^{5}\right]$ with $\mathrm{Co}\left(\mathrm{ClO}_{4}\right)_{2} \cdot 6 \mathrm{H}_{2} \mathrm{O}$. The latter reaction resulted in a compound formulated as $\left[\mathrm{Co}_{2}{ }_{2} \mathrm{Co}_{2}{ }_{2}(\mathrm{MeO})_{4}\left(\mathrm{~L}^{5}\right)_{2} \mathrm{Cl}_{2}\right]$ (10) (Fig. S4, Table S11 $\dagger$ ) possessing a defective dicubane or 2,3M4-1 topology, indicating sensitivity to oxidation. The transformation of the perchlorate anion to a chlorine anion is not unusual and has been seen before. ${ }^{72,73}$ More crystallographic data are necessary to perform a complete structural comparison; however, the present findings indicate that $\mathrm{HL}^{1}$, despite offering similar coordination sites to other similar diprotic ligands, coordinates completely different from them and thus its coordination chemistry can lead to new, interesting and unprecedented topologies.

\section{Synthetic issues}

A detailed analysis of the synthetic aspects for the afforded compounds 1-9 provides very interesting points. There are a few parameters that influence the resulting structures. Among these parameters are a) the solvent which was used, b) the temperature in which the syntheses took place and c) the metal source used. From the resulting compounds it becomes evident that these attributes not only affect the metal nuclearity and the coordination modes of the ligand to the metal centres but also facilitate the ligand transformations which were observed in compounds 4-7.

With regard to the solvent which was used, the afforded compounds can be divided into two categories: a) those which were obtained using a polar solvent such as methanol (compounds 4, 8, 9) and b) those which were obtained using a non-polar solvent, i.e. acetonitrile (compounds 1-3, 5-7). An immediate observation is the change in the metal nuclearity which also seems to be connected to the ligand transformations; the reaction in protic solvent affords compounds 4,8 and 9 which are either dimers or tetramers $\left(\mathrm{Co}_{4}\right.$, $\mathrm{Ni}_{2}, \mathrm{Cu}_{4}$ ); however, upon using acetonitrile, the respective monomeric $\mathrm{Co}$ (1), $\mathrm{Ni}$ (2), and $\mathrm{Cu}$ (3) compounds are obtained. In addition, the room temperature reaction of $\mathrm{Co}\left(\mathrm{ClO}_{4}\right)_{2} \cdot 6 \mathrm{H}_{2} \mathrm{O}$ with $\mathrm{HL}^{1}$ in $\mathrm{MeCN}$ results in a powder crystalline material in low yield which was found to be the mononuclear compound 1; however, a similar reaction in $\mathrm{MeOH}$ results in the formation of the tetranuclear $\mathrm{Co}^{\mathrm{II}} 4$.

It is well known that Co-based catalysts have been used in the oxidation of alkanes for the synthesis of terephthalic acid or adipic acid involving molecular $\mathrm{O}_{2} \cdot{ }^{74}$ In Table 1 , a synthetic overview of the synthesis of compounds 1, 4, 5, 6 and 7 is given, where transformation of the organic ligand is observed. With regard to the temperature in which the syntheses of the aforementioned compounds took place two major conclusions can be drawn. a) The room temperature reaction of $\mathrm{HL}^{1}$ with $\mathrm{Co}\left(\mathrm{ClO}_{4}\right)_{2} \cdot 6 \mathrm{H}_{2} \mathrm{O}$ in MeCN afforded compound 1 (entry 2); however, when a similar reaction is performed under reflux, a ligand transformation occurs $\left(\mathrm{H}_{3} \mathrm{~L}^{3}\right.$, Scheme 1), affording compound 6 (entry 7). b) A comparison of the synthetic protocol of compounds 5 and 7 indicates that these two molecules were derived using the same metal salt $\mathrm{Co}(\mathrm{OAc})_{2} \cdot 4 \mathrm{H}_{2} \mathrm{O}$, solvent $(\mathrm{MeCN})$ and metal-ligandbase ratio (4:5:5); however, room temperature conditions favor the formation of a cobalt tetramer with the transformed $\mathrm{L}^{2}$ ligand found in 5 (entry 4 ), while reflux conditions lead towards the synthesis of a cobalt monomer with a mix of $\mathrm{L}^{1}$ and $\mathrm{L}^{4}$ ligands, found in 7 (entries 4 and 8, respectively).

From this table, another two important notes can be pointed out, both related with the synthesis of compound 6 . First, repeating the room temperature reaction that affords 5 and layering the resultant solution with $\mathrm{Et}_{2} \mathrm{O}$ affords compound 6 (entry 5). Second, the latter compound can be obtained from the reaction of $\mathrm{HL}^{1}$ with $\mathrm{Co}\left(\mathrm{BF}_{4}\right)_{2} \cdot 6 \mathrm{H}_{2} \mathrm{O}$ in MeCN under reflux conditions (entry 6). With regard to the organic ligand's transformations found in 5, 6 and 7 (entries 4-8), these are dependent on i) the temperature (entries 4 and 8), ii) the Co source used (entries 6-8) and iii) the presence of $\mathrm{Et}_{2} \mathrm{O}$ (entry 5).

\section{Computational mechanistic studies}

A comprehensive and consistent picture of the transformations that the coordinated ligands to Co complexes under study undergo ( $c f$. Scheme 1) has been derived by means of DFT calculations employing the PBE0/Def2-TZVP(Co) $U$ 6-31G(d,p)(E) (E = main group element) computational protocol. All crucial reaction steps have been scrutinized by examining the participation of $\mathrm{Co}-\mathrm{O}_{2}$ intermediates in terms of located structures, energies and activation barriers. First we calculated the equilibrium geometries and the electronic

Table 1 Synthetic overview of compounds 1 and 4-7

\begin{tabular}{|c|c|c|c|c|c|c|}
\hline Entries & Metal salt & $T$ & Solvent & Ratio (M : L : B) & Compound & Ligand \\
\hline 1 & $\mathrm{CoBr}_{2}$ & Reflux & MeCN & $4: 5: 5$ & 1 & $\mathrm{~L}^{1}$ \\
\hline 2 & $\mathrm{Co}\left(\mathrm{ClO}_{4}\right)_{2} \cdot 6 \mathrm{H}_{2} \mathrm{O}$ & r.t. & MeCN & $4: 5: 5$ & 1 & $\mathrm{~L}^{1}$ \\
\hline 3 & $\mathrm{Co}\left(\mathrm{ClO}_{4}\right)_{2} \cdot 6 \mathrm{H}_{2} \mathrm{O}$ & r.t. & MeOH & $2: 5: 5$ & 4 & $\mathrm{~L}^{1}$ \\
\hline 4 & $\mathrm{Co}(\mathrm{OAc})_{2} \cdot 4 \mathrm{H}_{2} \mathrm{O}$ & r.t. & MeCN & $4: 5: 5$ & 5 & $\mathrm{~L}^{2}$ \\
\hline 5 & $\mathrm{Co}(\mathrm{OAc})_{2} \cdot 4 \mathrm{H}_{2} \mathrm{O}$ & r.t. & $\mathrm{MeCN}, \mathrm{Et}_{2} \mathrm{O}$ & $2: 5: 10$ & 6 & $\mathrm{~L}^{3}$ \\
\hline 6 & $\mathrm{Co}\left(\mathrm{BF}_{4}\right)_{2} \cdot 6 \mathrm{H}_{2} \mathrm{O}$ & Reflux & MeCN & $4: 5: 10$ & 6 & $\mathrm{~L}^{3}$ \\
\hline 7 & $\mathrm{Co}\left(\mathrm{ClO}_{4}\right)_{2} \cdot 6 \mathrm{H}_{2} \mathrm{O}$ & Reflux & MeCN & $4: 5: 20$ & 6 & $\mathrm{~L}^{3}$ \\
\hline 8 & $\mathrm{Co}(\mathrm{OAc})_{2} \cdot 4 \mathrm{H}_{2} \mathrm{O}$ & Reflux & MeCN & $4: 5: 5$ & 7 & $\mathrm{~L}^{1}, \mathrm{~L}^{4}$ \\
\hline
\end{tabular}


structure of the "free" ligands $\mathrm{L}^{n}(n=1-4)$ in MeCN solutions. Fig. 5 shows the ground-state geometries of the "free" ligands $\mathrm{L}^{n}$, the natural atomic charges on selected atoms and the frontier molecular orbitals relevant to coordination of the ligands in MeCN solutions calculated by the PBE0/6-31G(d,p)/ PCM computational protocol.

Perusal of the highest occupied molecular orbitals (HOMOs) of the "free" $\mathrm{L}^{n}$ ligands reveals that the electron density is primarily localized on the phenoxide moieties including also the localization on the $2 \mathrm{p}$ AOs of the $\mathrm{O}$ and $\mathrm{N}$ donor atoms of the ligands. These atoms acquire negative natural atomic charges, namely $-0.667-0.722|\mathrm{e}|$ on the phenoxide $\mathrm{O}$ atom, $-0.592-0.677|\mathrm{e}|$ on the carbonyl group $\mathrm{O}$ atom, $-0.526-0.531|\mathrm{e}|$ on the methoxide $\mathrm{O}$ atom and $-0.514-0.576 \mid$ e| on the imine group nitrogen atom. Both the nature of the HOMOs and the negative natural atomic charges show that all these atoms could participate in the coordination of the $\mathrm{L}^{n}$ ligands to the Co central atom, thus explaining all coordination modes observed experimentally (Scheme S1†).

To probe the "distant" intramolecular $\mathrm{C}-\mathrm{H}$ bond activation by the coordinated superoxide ligand of the $\mathrm{C}-\mathrm{H}$ bonds of the $-\mathrm{CH}_{3},-\mathrm{CH}_{2} \mathrm{OH}$ and $-\mathrm{CH}(\mathrm{OH})_{2}$ substituents on the $\mathrm{C}$ atom of the pyrazolone ring of the ligands $\mathrm{L}^{n}$ that promotes the $\mathrm{L}^{1} \rightarrow \mathrm{L}^{2} \rightarrow \mathrm{L}^{3} \rightarrow \mathrm{L}^{3^{\prime}} \rightarrow \mathrm{L}^{4}$ ligand transformations, the reaction trajectory was explored through DFT calculations of the potential energy surfaces (PESs) and monitoring the geometric and energy reaction profiles (Fig. 6-8). A possible reaction mechanism is shown in Scheme 3.

In the first step, the $\left[\mathrm{L}^{n} \mathrm{Co}^{\mathrm{II}}\right]^{+}$complexes interact with dioxygen forming the superoxo $\left[\mathrm{L}^{n} \mathrm{Co}\left(\mathrm{O}-\mathrm{O}^{--}\right)\right]^{+}$adducts. The formation of the superoxo $\left[\mathrm{L}^{n} \mathrm{Co}\left(\mathrm{O}-\mathrm{O}^{\cdot-}\right)\right]^{+}$adducts correspond to exothermic processes, and the estimated exothermicities are around -18.1-18.5 $\mathrm{kcal} \mathrm{mol}^{-1}$ at the PBE0/Def2-TZVP(Co) $\cup 6-31 \mathrm{G}(\mathrm{d}, \mathrm{p})(\mathrm{E}) / \mathrm{PCM}$ level of theory. In the superoxo $\left[\mathrm{L}^{n} \mathrm{Co}-\right.$ $\left.\left(\mathrm{O}-\mathrm{O}^{\cdot-}\right)\right]^{+}$complexes the spin density, which was localized at

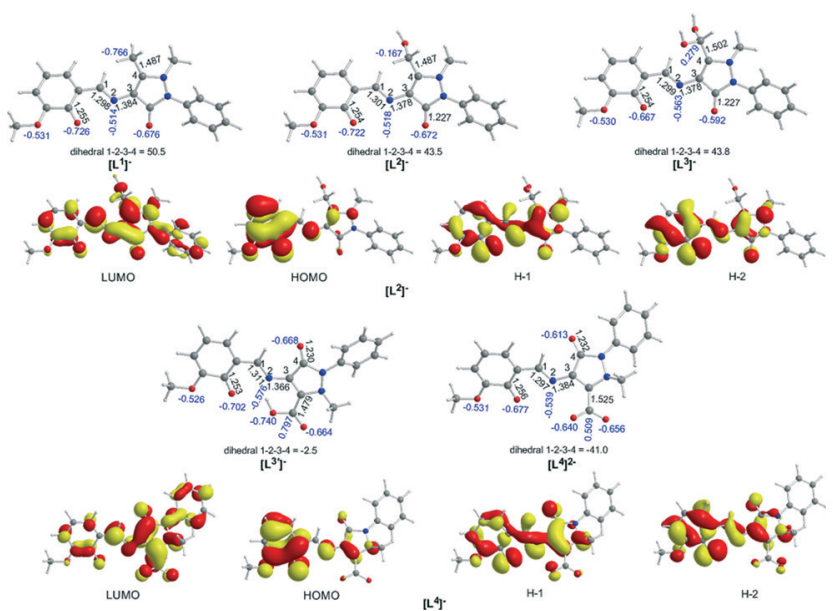

Fig. 5 Equilibrium geometries of the "free" ligands $L^{n}$, the natural atomic charges on selected atoms (in blue) and the frontier molecular orbitals relevant to coordination of the ligands in $\mathrm{MeCN}$ solutions calculated by the PBE0/6-31G(d,p)/PCM computational protocol.

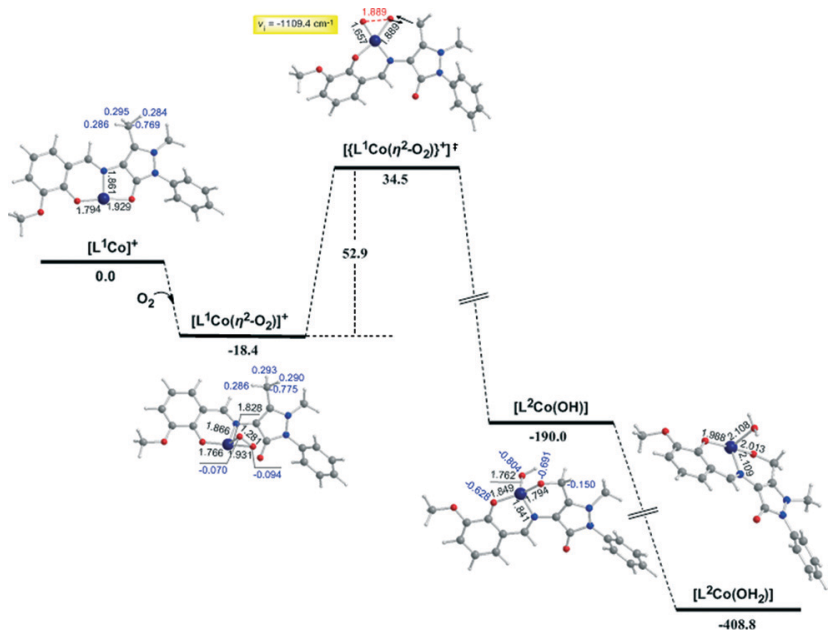

Fig. 6 Geometric and energy profiles of the reaction trajectory for the intramolecular transformation of coordinated ligand $L^{1}$ to $L^{2}$ calculated by the PBE0/Def2-TZVP(Co) $\cup 6-31 \mathrm{G}(\mathrm{d}, \mathrm{p})(\mathrm{E}) / \mathrm{PCM}$ (E = main group element) computational protocol.

the metal centre in the precursor $\left[\mathrm{L}^{n} \mathrm{Co}^{\mathrm{II}}\right]^{+}$complexes, is now localized at the superoxide ligand (Scheme 4).

An inspection of Fig. 6-8 reveals that the $\left[\mathrm{L}^{n} \mathrm{Co}\right]^{+}(n=1-3)$ complexes of $\mathrm{Co}^{\mathrm{II}}$ in their doublet ground states bind $\mathrm{O}_{2}$ in an asymmetric side-on $\eta^{2}-\mathrm{O}_{2}$ coordination mode with an $\mathrm{O}-\mathrm{O}$ bond length of $1.28 \AA$, intermediate between the values of $1.21 \AA$ for $\mathrm{O}_{2}$ and $1.34 \AA$ for $\mathrm{O}_{2}{ }^{2-}$. This bonding mode involving a one-electron transfer from the $\mathrm{Co}^{\mathrm{II}}$ metal centre to the dioxygen ligand gives rise to the formation of superoxo $\left[\mathrm{L}^{n} \mathrm{Co}-\right.$ $\left.\left(\mathrm{O}-\mathrm{O}^{--}\right)\right]^{+}$complexes. In the superoxo $\left[\mathrm{L}^{n} \mathrm{Co}\left(\mathrm{O}-\mathrm{O}^{--}\right)\right]^{+}$complexes the $\mathrm{Co}-\mathrm{O}$ bond lengths for the shorter $\mathrm{Co}-\mathrm{O}$ bonds are 1.866, $1.839,1.827$ and $1.822 \AA$ for the $\left.\mathrm{L}^{1} \mathrm{Co}\left(\mathrm{O}-\mathrm{O}^{--}\right)\right]^{+}$, $\left.\left.\mathrm{L}^{2} \mathrm{Co}\left(\mathrm{O}-\mathrm{O}^{\cdot-}\right)\right]^{+}, \quad \mathrm{L}^{3} \mathrm{Co}\left(\mathrm{O}-\mathrm{O}^{\cdot-}\right)\right]^{+}$and $\left.\mathrm{L}^{3^{\prime}} \mathrm{Co}\left(\mathrm{O}-\mathrm{O}^{\cdot-}\right)\right]^{+}$complexes,

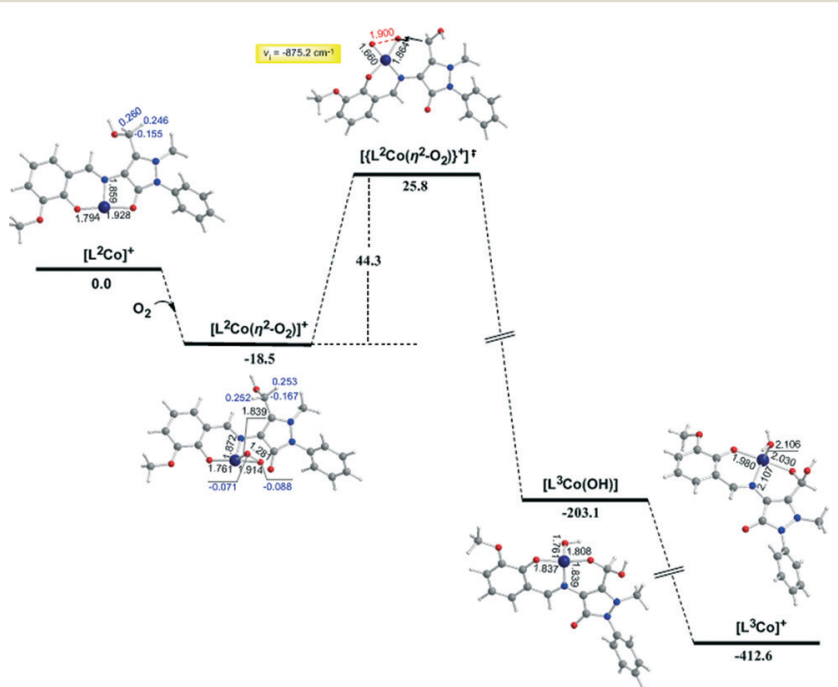

Fig. 7 Geometric and energy profiles of the reaction trajectory for the intramolecular transformation of coordinated ligand $\mathrm{L}^{2}$ to $\mathrm{L}^{3}$ calculated by the PBE0/Def2-TZVP(Co) $\cup 6-31 \mathrm{G}(\mathrm{d}, \mathrm{p})(\mathrm{E}) / \mathrm{PCM}(\mathrm{E}=$ main group element) computational protocol. 


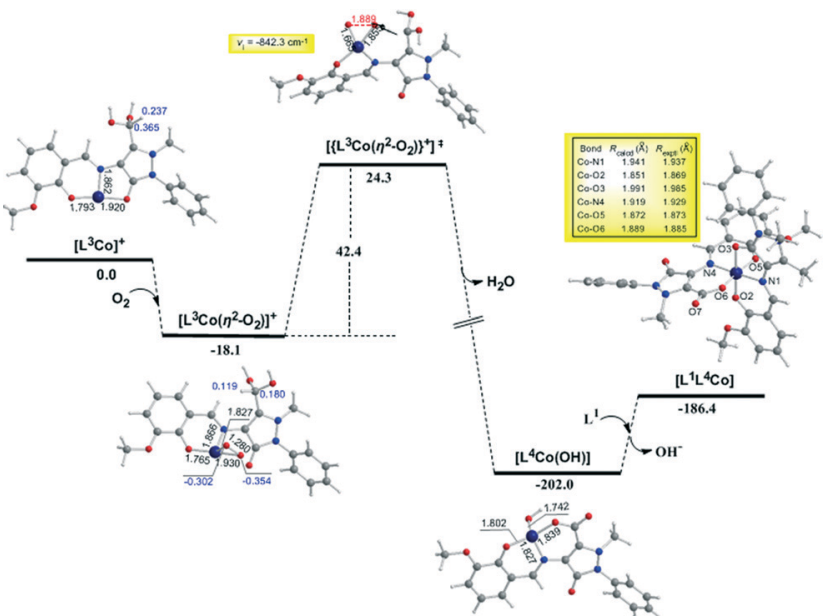

Fig. 8 Geometric and energy profiles of the reaction trajectory for the intramolecular transformation of coordinated ligand $L^{3}$ to $L^{4}$ calculated by the PBE0/Def2-TZVP(Co) $\cup 6-31 \mathrm{G}(\mathrm{d}, \mathrm{p})(\mathrm{E}) / \mathrm{PCM}(\mathrm{E}=$ main group element) computational protocol.

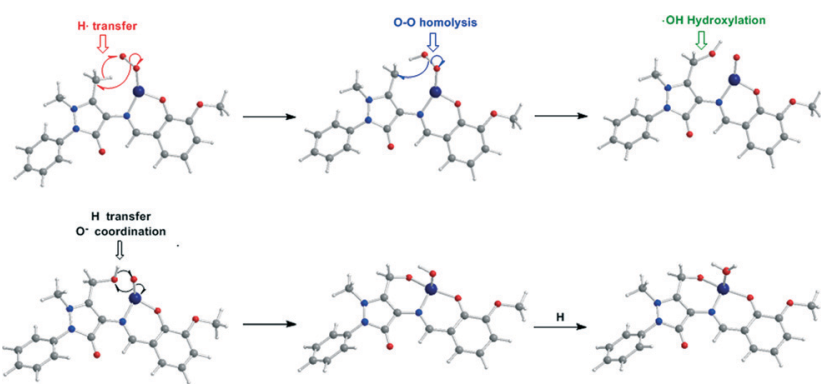

Scheme 3 Proposed mechanism for the intramolecular ligand transformations induced by the $\left[\mathrm{L}^{n} \mathrm{CO}{ }^{\prime \prime}\right]^{+}$model complexes.

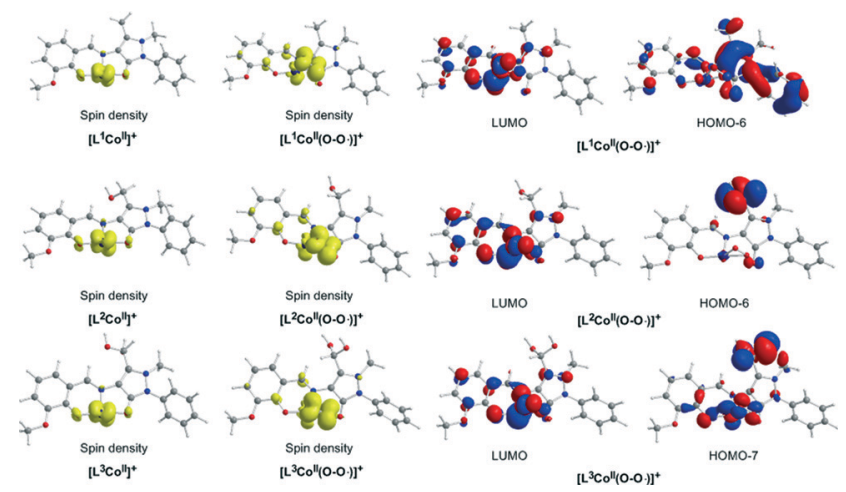

Scheme 4 3D plots of the spin density distribution (isospin surfaces = $0.002)$ in the $\left[\mathrm{L}^{n} \mathrm{Co}\right]^{\prime \prime}$ and $\left[\mathrm{L}^{n} \mathrm{Co}\left(\mathrm{O}-\mathrm{O}^{-}\right)\right]^{+}(n=1-3)$ model complexes along with the 3D plots of the molecular orbitals of the $\left[\mathrm{L}^{n} \mathrm{Co}\left(\mathrm{O}-\mathrm{O}^{--}\right)\right]^{+}$ complexes which support the hydrogen transfer.

respectively, and for the longer Co-O bonds are 1.931, 1.914, 1.930 and $1.937 \AA$, respectively.

It is worth noting that in 1:1 metal- $\mathrm{O}_{2}$ complexes both the end-on ( $\left.\eta^{1}-\right)$ and the side-on $\left(\eta^{2}\right.$-) bonding modes have been identified so far and the corresponding adducts were defined as superoxo or peroxo complexes, respectively, based primarily on the X-ray structural data ( $\mathrm{O}-\mathrm{O}$ bond distance) and vibrational spectra $\left(\mathrm{O}-\mathrm{O}\right.$ stretching frequency, $\left.v_{\mathrm{O}-\mathrm{O}}\right){ }^{75-79}$

In particular, when the $\mathrm{O}-\mathrm{O}$ bond length is $\approx 1.4-1.5 \AA$ and the $v_{\mathrm{O}-\mathrm{O}} \approx 800-930 \mathrm{~cm}^{-1}$ the compounds are designated as peroxides, whereas when $\mathrm{O}-\mathrm{O} \approx 1.2-1.3 \AA$ and $v_{\mathrm{O}-\mathrm{O}} \approx$ $1050-1200 \mathrm{~cm}^{-1}$ the compounds are characterized as superoxides. In the model $\left[\mathrm{L}^{n} \mathrm{Co}\left(\mathrm{O}_{-} \mathrm{O}^{\cdot-}\right)\right]^{+}$complexes the $\mathrm{O}-\mathrm{O}$ bond length of $1.28 \AA$ and the unscaled $v_{\mathrm{O}-\mathrm{O}}$ stretching vibrational frequencies around $1299-1317 \mathrm{~cm}^{-1}$ illustrate their superoxo character. Although for the superoxide ligand the more common coordination is the end-on coordination $\left(\eta^{1}-\mathrm{O}_{2}\right)$ it is also well-coordinated in the side-on fashion $\left(\eta^{2}-\mathrm{O}_{2}\right),{ }^{80,81}$ as in the case of the model $\left[\mathrm{L}^{n} \mathrm{Co}\left(\mathrm{O}-\mathrm{O}^{\cdot-}\right)\right]^{+}$complexes. The calculated Co- $\mathrm{N}_{\text {imine }}$ distances in the $\left[\mathrm{L}^{n} \mathrm{Co}\right]^{+}$and $\left[\mathrm{L}^{n} \mathrm{Co}\left(\mathrm{O}_{2}\right)\right]^{+}$model complexes are found in the range 1.859-1.867 $\AA$ and 1.849$1.872 \AA$, respectively, while the $\mathrm{Co}-\mathrm{O}_{\text {phenoxide }}$ distances are found in the range 1.918-1.929 $\AA$ and 1.917-1.937 $\AA$, respectively.

The coordinated superoxo radical abstracts a hydrogen atom through a homolytic $\mathrm{C}-\mathrm{H}$ bond cleavage $(\mathrm{H} \cdot$ transfer) supported by both electrostatic and orbital interactions. An intramolecular electrophilic attack of the $\mathrm{C}$ atom of the $-\mathrm{CH}_{3}$ and $-\mathrm{CH}_{2} \mathrm{OH}$ groups by the negatively charged coordinated superoxo radicals is precluded due to the negative natural atomic charges bearing the $\mathrm{C}$ atoms of these groups $(-\mathbf{0 . 7 7 5}$ and $-0.167|\mathrm{e}|$, respectively). The orbital interactions supporting the hydrogen transfer in the $\left[\mathrm{L}^{n} \mathrm{Co}\left(\mathrm{O}_{-} \mathrm{O}^{--}\right)\right]^{+}$complexes correspond predominantly to HOMO- $6 \leftrightarrow$ LUMO and HOMO-7 $\hookrightarrow$ LUMO interactions (Scheme 4). After the hydrogen abstraction of the $\mathrm{C}-\mathrm{H}$ bond, a homolytic $\mathrm{O}-\mathrm{O}$ bond cleavage (O-O homolysis) in the $\mathrm{Co}^{\mathrm{II}}-\mathrm{OOH}$ species takes place, affording $\mathrm{Co}^{\mathrm{III}}=\mathrm{O}\left(\leftrightarrow \mathrm{Co}^{\mathrm{II}}-\mathrm{O}\right)$ and $\mathrm{HO}^{\bullet}$ radical, which attacks the $\mathrm{C}$ atoms of the $\mathrm{CH}_{3}, \mathrm{CH}_{2} \mathrm{OH}$ and $\mathrm{CH}(\mathrm{OH})_{2}$ groups in a nearly concerted fashion ( ${ }^{\circ} \mathrm{OH}$ hydroxylation), yielding the hydroxylated ligands $\mathrm{L}^{2}, \mathrm{~L}^{3}$ and $\mathrm{L}^{3^{\prime}}$ predominantly (Fig. 6-8). Furthermore, the active $\mathrm{Co}^{\mathrm{III}}=\mathrm{O}\left(\leftrightarrow \mathrm{Co}^{\mathrm{II}}-\mathrm{O}\right)$ species generated after the homolytic $\mathrm{O}-\mathrm{O}$ bond cleavage could perform cooperatively a second $\mathrm{C}-\mathrm{H}$ bond cleavage step ( $\mathrm{H} \cdot$ transfer) yielding the $\left[\mathrm{L}^{n} \mathrm{Co}(\mathrm{OH})\right](n=2-4)$ intermediates, which subsequently are transformed to the $\left[\mathrm{L}^{2} \mathrm{Co}\left(\mathrm{OH}_{2}\right)\right],\left[\mathrm{L}^{3} \mathrm{Co}\left(\mathrm{OH}_{2}\right)\right]$ and $\left[\mathrm{L}^{1} \mathrm{~L}^{4} \mathrm{Co}\right]$ products. These transformations are predicted to be highly exothermic; the estimated exothermicities are -190.0 , -203.1 and $-202.0 \mathrm{kcal} \mathrm{mol}^{-1}$ for the $\mathrm{L}^{1} \rightarrow \mathrm{L}^{2}, \mathrm{~L}^{2} \rightarrow \mathrm{L}^{3}$ and $\mathrm{L}^{3}$ $\rightarrow \mathrm{L}^{4}$ ligand transformations, respectively. The superoxo $\left[\mathrm{L}^{n} \mathrm{Co}\left(\mathrm{O}-\mathrm{O}^{\cdot-}\right)\right]^{+}$complexes are transformed to $\left[\mathrm{L}^{n} \mathrm{Co}(\mathrm{OH})\right](n=$ 2-4) intermediates through the $\left[\left\{\mathrm{L}^{n} \mathrm{Co}\left(\mathrm{O}_{2}\right)\right\}^{+}\right]^{\neq}$transition states surmounting an activation barrier of 52.9, 44.3 and $42.4 \mathrm{kcal} \mathrm{mol}^{-1}$ for the $\mathrm{L}^{1} \rightarrow \mathrm{L}^{2}, \mathrm{~L}^{2} \rightarrow \mathrm{L}^{3}$ and $\mathrm{L}^{3} \rightarrow \mathrm{L}^{4}$ ligand transformations, respectively. The lowering of the activation barrier along the $\mathrm{L}^{1} \rightarrow \mathrm{L}^{2}, \mathrm{~L}^{2} \rightarrow \mathrm{L}^{3}$ and $\mathrm{L}^{3} \rightarrow \mathrm{L}^{4}$ ligand transformations could be attributed to the increase in the electrophilic character of the $\mathrm{C}$ atom of the $-\mathrm{CH}_{3},-\mathrm{CH}_{2} \mathrm{OH}$ and $\mathrm{CH}(\mathrm{OH})_{2}$ groups, which facilitates the ${ }^{\circ} \mathrm{OH}$ hydroxylation process. An analogous reaction trajectory was proposed by Wada and co-workers ${ }^{82}$ for the stoichiometric oxidation of 
substrates by the non-heme mononuclear hydroperoxo-Fe ${ }^{\text {III }}$ complex and more recently by Li et $a l^{83}$ in the proposed mechanism of dioxygen-activating non-heme enzymes.

\section{Magnetic studies}

The room temperature $\chi T$ value for compound 4 under an applied field of $3000 \mathrm{G}$ is $8.64 \mathrm{~cm}^{3} \mathrm{~K} \mathrm{~mol}^{-1}$ which is higher than that of the spin only value of $7.48 \mathrm{~cm}^{3} \mathrm{~K} \mathrm{~mol}^{-1}$ for four $\mathrm{Co}^{\mathrm{II}}$ (Co ${ }^{\mathrm{II}} ; S=3 / 2$ and $g=2.0$ ). The $\chi T$ value gradually decreases with decreasing temperature, reaching a plateau at around $10-20 \mathrm{~K}$ and then sharply falls down to $5.17 \mathrm{~cm}^{3}$ $\mathrm{K} \mathrm{mol}^{-1}$ at $1.8 \mathrm{~K}$. (Fig. 9). The non-continuous $\chi^{T}$ decay evidences some coupling inside the cube in addition to the usual $D_{\text {ion. }}$ To have a rough approach to the $\mathrm{Co}^{\mathrm{II}} \cdots \mathrm{Co}^{\mathrm{II}}$ interactions, fitting of the experimental data was performed with the PHI program, ${ }^{84}$ assuming a distorted cube of four $S=3 / 2$ spins on the basis of the Hamiltonian $H=-J_{1}\left(S_{1} \cdot S_{4}+S_{2} \cdot S_{3}\right)-$ $J_{2}\left(S_{1} \cdot S_{2}+S_{1} \cdot S_{3}\right)-J_{3}\left(S_{2} \cdot S_{3}+S_{2} \cdot S_{4}\right)$, which corresponds to a cube with similar interactions in opposite faces. Taking into account a $D_{\text {ion }}$ term, an excellent fit was obtained for the parameters $J_{1}=+4.4 \mathrm{~cm}^{-1}, J_{2}=+1.3 \mathrm{~cm}^{-1}, J_{3}=-1.4 \mathrm{~cm}^{-1}, g=$ 2.12 and $D_{\text {ion }}=18.8 \mathrm{~cm}^{-1}$. The positive $J_{1}$ interaction can be assigned to the pair of faces with smaller Co-O-Co bond angles, close to $94-95^{\circ}$. Magnetization experiments performed at $2 \mathrm{~K}$ show a constant increase of magnetization up to a quasi-saturated value equivalent to 5.91 electrons under the maximum external field of $5 \mathrm{~T}$, (Fig. 9, inset). Each $\mathrm{Co}^{\text {II }}$ can be treated as an effective $S=1 / 2$ spin at low temperature due to the ZFS, and thus the magnetization must behave as a strongly anisotropic effective $S=2$ spin level. The fit of the magnetization, assuming the above response, gives an excellent agreement for $D_{\mathrm{S}=2}=-1.7 \mathrm{~cm}^{-1}$ and $g=3.10$.

The room temperature $\chi_{M} T$ value for compound 8 is 2.57 $\mathrm{cm}^{3} \mathrm{~K} \mathrm{~mol}^{-1}$, which is higher than that of the spin only value of $2.33 \mathrm{~cm}^{3} \mathrm{~K} \mathrm{~mol}^{-1}$ for two $\mathrm{Ni}^{\mathrm{II}}$ (Fig. 10). Upon cooling, this value starts to increase to a maximum value of $2.62 \mathrm{~cm}^{3}$ $\mathrm{K} \mathrm{mol}^{-1}$ at $20 \mathrm{~K}$ and then decreases to $1.68 \mathrm{~cm}^{3} \mathrm{~K} \mathrm{~mol}^{-1}$ at 2 K. Magnetization measurements show a continuous increase

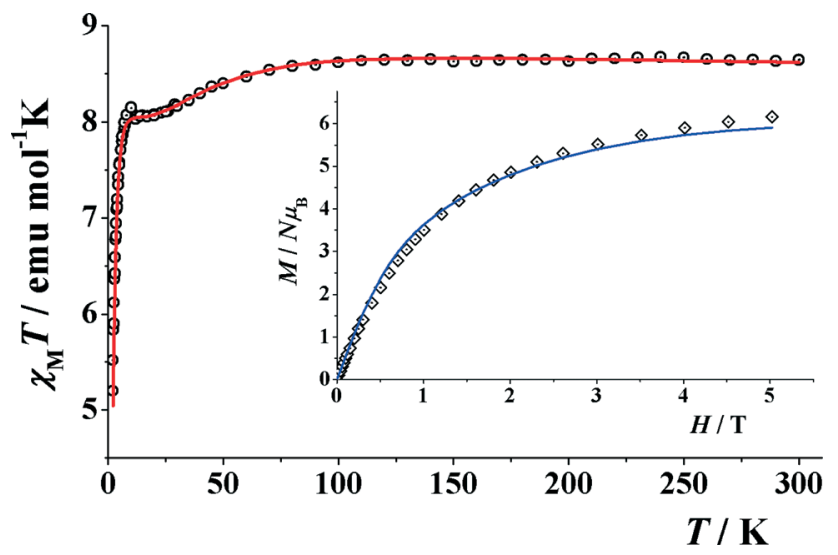

Fig. 9 Product of $\chi_{M}$ vs. $T$ for compound 4. (Inset) Magnetization plot in the range $0-5 \mathrm{~T}$. Solid lines show the best obtained fits.

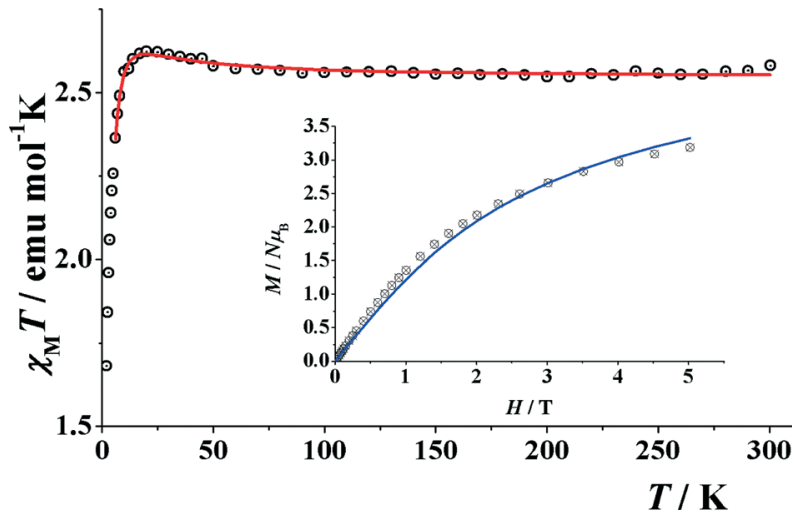

Fig. 10 Product of $\chi_{M}$ vs. $T$ for compound 8. (Inset) Magnetization plot in the range $0-5 \mathrm{~T}$. Solid lines show the best obtained simultaneous fit.

of magnetization up to a maximum value equivalent to 3.2 electrons. This behavior suggests weak ferromagnetic coupling with an $S=2$ ground state and a significant $D$ contribution. Simultaneous fit of the experimental data was performed, applying the Hamiltonian $H=-J\left(S_{1} \cdot S_{2}\right)$ and including a $D_{\text {ion }}$ parameter. Least-squares fitting of the experimental data gave the common values of $J=+1.2 \mathrm{~cm}^{-1}, g=$ $2.255, D=3.79 \mathrm{~cm}^{-1}$ for both measurements. The fit confirms an $S=2$ ground state for 8 .

\section{Conclusions}

In this work we have successfully, for the first time, employed the monoanionic Schiff base ligand $\left(\mathrm{HL}^{1}\right.$, Scheme 1$)$ derived from the condensation of $o$-vanillin and 4-aminoantipyrine in cobalt, nickel and copper chemistry to access nine new CCs. A topological evaluation of all polynuclear CCs obtained is reported. In addition, a structural comparison of the present polynuclear CCs along with the compounds derived from structurally related ligands is attempted (Scheme 2). We conclude that a) $\mathrm{HL}^{1}$ coordinates completely different from them and thus its coordination chemistry can lead to new, interesting and unprecedented topologies and b) more synthetic studies are required to reach a point wherein the design of such species can be undertaken. ${ }^{85}$ In addition, we report interesting cases of ligand transformations (Scheme 1), which take place in certain experiments with cobalt sources (4-7). These transformations occur in one of the methyl groups of the pyrazolone ring of the HL ligand under specific conditions such as the use of a particular metal salt, ratio and solvent, altering drastically the coordination mode of the ligand and resulting in different structures. DFT calculations of the potential energy surfaces (PESs) and monitoring the geometric and energetic reaction profiles of the intramolecular $\mathrm{L}^{1} \rightarrow$ $\mathrm{L}^{2} \rightarrow \mathrm{L}^{3} \rightarrow \mathrm{L}^{3^{\prime}} \rightarrow \mathrm{L}^{4}$ ligand transformations revealed a possible reaction mechanism that involves the formation of superoxo $\left[\mathrm{L}^{n} \mathrm{Co}\left(\mathrm{O}_{-} \mathrm{O}^{--}\right)\right]^{+}$adducts, which are transformed to $\left[\mathrm{L}^{n} \mathrm{Co}-\right.$ $(\mathrm{OH})](n=2-4)$ intermediates through the $\left[\left\{\mathrm{L}^{n} \mathrm{Co}\left(\mathrm{O}_{2}\right)\right\}^{+}\right]^{\neq}$ transition states, surmounting an activation barrier of 52.9, 44.3 and $42.4 \mathrm{kcal} \mathrm{mol}^{-1}$ for the $\mathrm{L}^{1} \rightarrow \mathrm{L}^{2}, \mathrm{~L}^{2} \rightarrow \mathrm{L}^{3}$ and $\mathrm{L}^{3} \rightarrow$ 
$\mathrm{L}^{4}$ ligand transformations, respectively. These transformations involving concomitant $\mathrm{H}$ transfer, $\mathrm{O}-\mathrm{O}$ homolysis and ${ }^{\circ} \mathrm{OH}$ hydroxylation processes afford the $\left[\mathrm{L}^{n} \mathrm{Co}(\mathrm{OH})\right](n=2-4)$ intermediates that subsequently are transformed to the final products. The present findings indicate that the coordination chemistry of $\mathrm{HL}^{1}$ can lead to unprecedented CCs bearing interesting properties, and thus our future studies will be focused on further exploring it.

\section{Acknowledgements}

We thank the EPSRC UK National Crystallography Service at the University of Southampton for the collection of the crystallographic data for compounds 4, 7 and 8. Research development funding from the University of Sussex is gratefully acknowledged (V. N. D.). V. K. acknowledges University of Sussex for a Junior Research Award summer fellowship. Support from CICYT Project CTQ2012-30662 is acknowledged (A. E.)

\section{Notes and references}

1 L. Cronin and J. Fielden, in Coordination Clusters in Encyclopedia of Supramolecular Chemistry, Taylor \& Francis, London, 2007, pp. 1-10.

2 E. Ritter, P. Przybylski, B. Brzezinski and F. Bartl, Curr. Org. Chem., 2009, 13, 241-249.

3 M. S. Karthikeyan, D. J. Prasad, B. Poojary, K. Subrahmanya Bhat, B. S. Holla and N. S. Kumari, Bioorg. Med. Chem., 2006, 14, 7482-7489.

4 M. J. O'Donnell, Acc. Chem. Res., 2004, 37, 506-517.

5 R. J. P. Corriu, E. Lancelle-Beltran, A. Mehdi, C. Reyé, S. Brandès and R. Guilard, J. Mater. Chem., 2002, 12, 1355-1362.

6 R. J. P. Corriu, E. Lancelle-Beltran, A. Mehdi, C. Reyé, S. Brandès and R. Guilard, Chem. Mater., 2003, 15, 3152-3160.

7 F. Faridbod, M. R. Ganjali, R. Dinarvand, P. Norouzi and S. Riahi, Sensors, 2008, 8, 1645-1703.

8 K. C. Gupta and A. K. Sutar, Coord. Chem. Rev., 2008, 252, 1420-1450.

9 P. G. Cozzi, Chem. Soc. Rev., 2004, 33, 410-421.

10 D. Ramakrishna, B. R. Bhat and R. Karvembu, Catal. Commun., 2010, 11, 498-501.

11 Z. Ma, L. Wei, E. C. B. A. Alegria, L. M. D. R. S. Martins, M. F. C. Guedes da Silva and A. J. L. Pombeiro, Dalton Trans., 2014, 43, 4048-4058.

12 D. S. Nesterov, E. N. Chygorin, V. N. Kokozay, V. V. Bon, R. Boča, Y. N. Kozlov, L. S. Shul'pina, J. Jezierska, A. Ozarowski, A. J. L. Pombeiro and G. B. Shul'pin, Inorg. Chem., 2012, 51, 9110-9122.

13 C. M. Da Silva, D. L. Da Silva, L. V. Modolo, R. B. Alves, M. A. De Resende, C. V. B. Martins and Â. De Fátima, J. Adv. Res., 2011, 2, 1-8.

14 P. Vicini, A. Geronikaki, M. Incerti, B. Busonera, G. Poni, C. A. Cabras and P. La Colla, Bioorg. Med. Chem., 2003, 11, 4785-4789.
15 W. Chen, Y. Li, Y. Cui, X. Zhang, H. L. Zhu and Q. Zeng, Eur. J. Med. Chem., 2010, 45, 4473-4478.

16 H. Miyasaka, R. Clérac, W. Wernsdorfer, L. Lecren, C. Bonhomme, K.-I. Sugiura and M. Yamashita, Angew. Chem., Int. Ed., 2004, 43, 2801-2805.

17 S. Mandal, G. Rosair, J. Ribas and D. Bandyopadhyay, Inorg. Chim. Acta, 2009, 362, 2200-2204.

18 Z. Lü, M. Yuan, F. Pan, S. Gao, D. Zhang and D. Zhu, Inorg. Chem., 2006, 45, 3538-3548.

19 N. C. Anastasiadis, D. A. Kalofolias, A. Philippidis, S. Tzani, C. Raptopoulou, V. Psycharis, C. J. Milios, A. Escuer and S. P. Perlepes, Dalton Trans., 2015, 44, 10200-10209.

20 A. A. Athanasopoulou, M. Pilkington, C. P. Raptopoulou, A. Escuer and T. C. Stamatatos, Chem. Commun., 2014, 50, 14942-14945.

21 D. I. Alexandropoulos, T. N. Nguyen, L. Cunha-Silva, T. F. Zafiropoulos, A. Escuer, G. Christou and T. C. Stamatatos, Inorg. Chem., 2013, 52, 1179-1181.

22 A. B. Canaj, D. I. Tzimopoulos, A. Philippidis, G. E. Kostakis and C. J. Milios, Inorg. Chem., 2012, 51, 10461-10470.

23 A. B. Canaj, D. I. Tzimopoulos, A. Philippidis, G. E. Kostakis and C. J. Milios, Inorg. Chem. Commun., 2012, 51, 7451-7453.

24 K.-H. Chang, C.-C. Huang, Y.-H. Liu, Y.-H. Hu, P.-T. Chou and Y.-C. Lin, Dalton Trans., 2004, 1731-1738.

25 H.-C. Lin, C.-C. Huang, C.-H. Shi, Y.-H. Liao, C.-C. Chen, Y.-C. Lin and Y.-H. Liu, Dalton Trans., 2007, 781-791.

26 L. A. Saghatforoush, R. Mehdizadeh and F. Chalabian, Transition Met. Chem., 2010, 35, 903-910.

27 B. Tamami and S. Ghasemi, Appl. Catal., A, 2011, 393, 242-250.

28 E. C. Constable, C. E. Housecroft, J. A. Zampese and G. Zhang, Polyhedron, 2012, 44, 150-155.

29 C.-M. Liu, R.-G. Xiong, D.-Q. Zhang and D.-B. Zhu, J. Am. Chem. Soc., 2010, 132, 4044-4045.

30 S. Saha, S. Pal, C. J. Gómez-García, J. M. Clemente-Juan, K. Harms and H. P. Nayek, Polyhedron, 2014, 74, 1-5.

31 Y. Thio, S. W. Toh, F. Xue and J. J. Vittal, Dalton Trans., 2014, 43, 5998-6001.

32 H. Oshio, N. Hoshino, T. Ito, M. Nakano, F. Renz and P. Gütlich, Angew. Chem., Int. Ed., 2003, 42, 223-225.

33 N. Hoshino, A. M. Ako, A. K. Powell and H. Oshio, Inorg. Chem., 2009, 48, 3396-3407.

34 M. Sarwar, A. M. Madalan, C. Tiseanu, G. Novitchi, C. Maxim, G. Marinescu, D. Luneau and M. Andruh, New J. Chem., 2013, 37, 2280-2292.

35 Y.-N. Guo, X.-H. Chen, S. Xue and J. Tang, Inorg. Chem., 2012, 51, 4035-4042.

36 H. Ke, S. Zhang, W. Zhu, G. Xie and S. Chen, J. Coord. Chem., 2015, 68, 808-822.

37 H. Ke, W. Zhu, S. Zhang, G. Xie and S. Chen, Polyhedron, 2015, 87, 109-116.

38 Y.-Z. Zheng, Y. Lan, C. E. Anson and A. K. Powell, Inorg. Chem., 2008, 47, 10813-10815.

39 B. Gole, K. C. Mondal and P. S. Mukherjee, Inorg. Chim. Acta, 2014, 415, 151-164. 
40 K. C. Mondal, G. E. Kostakis, Y. Lan and A. K. Powell, Polyhedron, 2013, 66, 268-273.

41 M. Hasanzadeh, M. Salehi, M. Kubicki, S. M. Shahcheragh, G. Dutkiewicz, M. Pyziak and A. Khaleghian, Transition Met. Chem., 2014, 39, 623-632.

42 S. Nayak, H. P. Nayek, S. Dehnen, A. K. Powell and J. Reedijk, Dalton Trans., 2011, 40, 2699-2702.

43 F. H. Allen, Acta Crystallogr., Sect. B: Struct. Sci., 2002, 58, 380-388.

44 P. Bhowmik, N. Aliaga-Alcalde, V. Gómez, M. Corbella and S. Chattopadhyay, Polyhedron, 2013, 49, 269-276.

45 R. Ganguly, B. Sreenivasulu and J. J. Vittal, Coord. Chem. Rev., 2008, 252, 1027-1050.

46 E. Loukopoulos, B. Berkoff, A. Abdul-Sada, G. J. Tizzard, S. J. Coles, A. Escuer and G. E. Kostakis, Eur. J. Inorg. Chem., 2015, 2646-2649.

47 B. Berkoff, K. Griffiths, A. Abdul-Sada, G. J. Tizzard, S. Coles, A. Escuer and G. E. Kostakis, Dalton Trans., 2015, 44, 12788-12795.

48 K. C. Mondal, A. Sundt, Y. Lan, G. E. Kostakis, O. Waldmann, L. Ungur, L. F. Chibotaru, C. E. Anson and A. K. Powell, Angew. Chem., Int. Ed., 2012, 51, 7550-7554.

49 I. Nemec, M. Machata, R. Herchel, R. Boča and Z. Trávníček, Dalton Trans., 2012, 41, 14603-14610.

50 K. C. Mondal, G. E. Kostakis, Y. Lan, W. Wernsdorfer, C. E. Anson and A. K. Powell, Inorg. Chem., 2011, 50, 11604-11611.

51 M. Frisch, G. Trucks and H. Schlegel, Gaussian 09, Revision D.01; Gaussian, Inc., Wallingford, CT, 2010.

52 M. Ernzerhof and G. E. Scuseria, J. Chem. Phys., 1999, 110, 5029-5036.

53 C. Adamo and V. Barone, Chem. Phys. Lett., 1997, 274, 242-250.

54 C. Adamo and V. Barone, J. Chem. Phys., 1999, 110, 6158.

55 C. Adamo, G. E. Scuseria and V. Barone, J. Chem. Phys., 1999, 111, 2889.

56 C. Adamo and V. Barone, Theor. Chem. Accounts Theory, Comput. Model. (Theoretica Chim. Acta), 2000, 105, 169-172.

57 V. Vetere, C. Adamo and P. Maldivi, Chem. Phys. Lett., 2000, 325, 99-105.

58 J. Tomasi, B. Mennucci and R. Cammi, Chem. Rev., 2005, 105, 2999-3093.

59 S. J. Coles and P. A. Gale, Chem. Sci., 2012, 3, 683-689.

60 O. V. Dolomanov, A. J. Blake, N. R. Champness and M. Schröder, J. Appl. Crystallogr., 2003, 36, 1283-1284.

61 L. Palatinus and G. Chapuis, J. Appl. Crystallogr., 2007, 40, 786-790.

62 L. J. Farrugia, J. Appl. Crystallogr., 1999, 32, 837-838.
63 G. M. Sheldrick, Acta Crystallogr., Sect. A: Found. Adv., 2015, 71, 3-8.

64 G. M. Sheldrick, Acta Crystallogr., Sect. A: Found. Crystallogr., 2008, 64, 112-122.

65 A. L. Spek, J. Appl. Crystallogr., 2003, 36, 7-13.

66 C. F. Macrae, P. R. Edgington, P. McCabe, E. Pidcock, G. P. Shields, R. Taylor, M. Towler and J. Van De Streek, J. Appl. Crystallogr., 2006, 39, 453-457.

67 H. H. Thorp, Inorg. Chem., 1992, 31, 1585-1588.

68 J. L. Atwood and J. W. Steed, in Supramolecular Chemistry, 2nd Edition, 2009, p. 402.

69 G. E. Kostakis, V. A. Blatov and D. M. Proserpio, Dalton Trans., 2012, 41, 4634-4640.

70 H. Xiang, Y. Lan, L. Jiang, W.-X. Zhang, C. E. Anson, T.-B. Lu and A. K. Powell, Inorg. Chem. Commun., 2012, 16, 51-54.

71 Z. Puterová-Tokárová, V. Mrázová, J. Kožíšek, J. Valentová, B. Vranovičová and R. Boča, Polyhedron, 2014, 70, 52-58.

72 B. Bhattacharya, R. Dey, D. K. Maity and D. Ghoshal, CrystEngComm, 2013, 15, 9457-9464.

73 K. Griffiths, C. W. D. Gallop, A. Abdul-Sada, A. Vargas, O. Navarro and G. E. Kostakis, Chem. - Eur. J., 2015, 21, 6358-6361.

74 P. J. Perez, Alkane C-H Activation by Single-Site Metal Catalysis, Springer Netherlands, Dordrecht, 2012, vol. 38.

75 M. H. Gubelmann and A. F. Williams, Struct. Bonding, 1983, 55, 2-65.

76 H. A. O. Hill and D. G. Tew, Comprehensive Coordination Chemistry, Pergamon Press, Oxford, 1987.

77 C. J. Cramer, W. B. Tolman, K. H. Theopold and A. L. Rheingold, Proc. Natl. Acad. Sci. U. S. A., 2003, 100, 3635-3640.

78 J. W. Egan, B. S. Haggerty, A. L. Rheingold, S. C. Sendlinger and K. H. Theopold, J. Am. Chem. Soc., 1990, 112, 2445-2446.

79 A. Hess, M. R. Hörz, L. M. Liable-Sands, D. C. Lindner, A. L. Rheingold and K. H. Theopold, Angew. Chem., Int. Ed., 1999, 38, 166-168.

80 J. S. Valentine, Chem. Rev., 1973, 73, 235-245.

81 L. Vaska, Acc. Chem. Res., 1976, 9, 175-183.

82 A. Wada, S. Ogo, S. Nagatomo, T. Kitagawa, Y. Watanabe, K. Jitsukawa and H. Masuda, Inorg. Chem., 2002, 41, 616-618.

83 F. Li, K. K. Meier, M. A. Cranswick, M. Chakrabarti, K. M. Van Heuvelen, E. Münck and L. Que, J. Am. Chem. Soc., 2011, 133, 7256-7259.

84 N. F. Chilton, R. P. Anderson, L. D. Turner, A. Soncini and K. S. Murray, J. Comput. Chem., 2013, 34, 1164-1175.

85 E. V. Alexandrov, A. P. Shevchenko, A. A. Asiri and V. A. Blatov, CrystEngComm, 2015, 17, 2913-2924. 